UNIVERSIDADE DE SÃO PAULO

ESCOLA DE ENFERMAGEM

MARIA CECILIA RIBEIRO

\title{
COMPETÊNCIA PROFISSIONAL: A DIMENSÃO DO SABER- SER ÉTICO-PROFISSIONAL NAS PRÁTICAS DE SAÚDE DAS ENFERMEIRAS EM UNIDADE BÁSICA DE SAÚDE.
}

SÃO PAULO

2009 
MARIA CECILIA RIBEIRO

\section{COMPETÊNCIA PROFISSIONAL: A DIMENSÃO DO SABER- SER ÉTICO-PROFISSIONAL NAS PRÁTICAS DE SAÚDE DAS ENFERMEIRAS EM UNIDADE BÁSICA DE SAÚDE.}

Dissertação apresentada ao Programa de PósGraduação em Enfermagem, da Escola de Enfermagem da Universidade de São Paulo, para obtenção do título de Mestre em Enfermagem.

Área de concentração: Enfermagem em Saúde Coletiva.

Orientadora:

Profa. Dra. Rosa Maria Serpa Godoy da Fonseca

SÃO PAULO

2009 


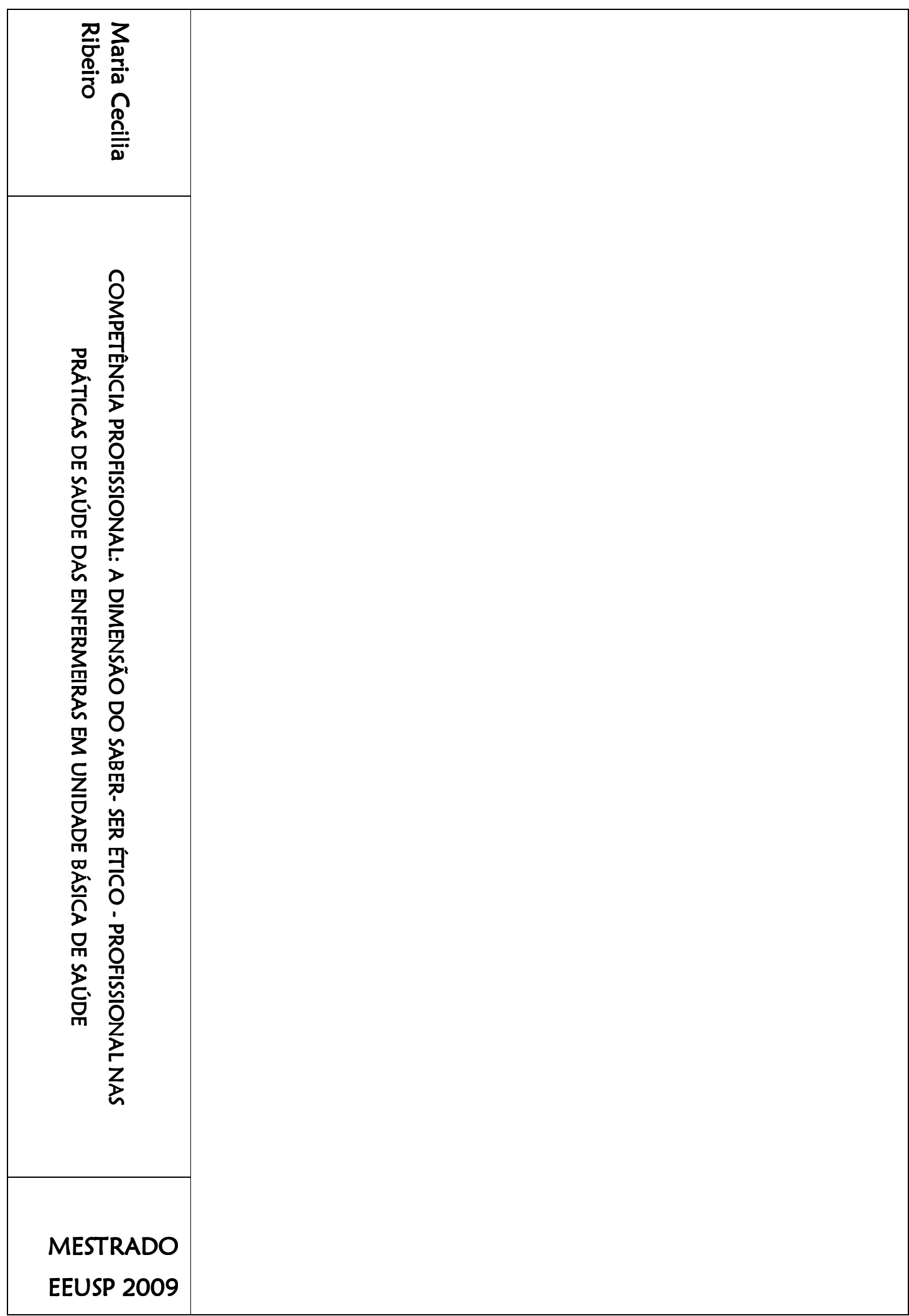


AUTORIZO A REPRODUÇÃO TOTAL OU PARCIAL DESTE TRABALHO, POR QUALQUER MEIO CONVENCIONAL OU ELETRÔNICO, PARA FINS DE ESTUDO E PESQUISA, DESDE QUE CITADA A FONTE.

Assinatura: Data 1

\section{Catalogação na Publicação (CIP) \\ Biblioteca "Wanda de Aguiar Horta" \\ Escola de Enfermagem da Universidade de São Paulo}

Ribeiro, Maria Cecília.

Competência profissional: a dimensão do saber - ser éticoprofissional nas práticas de saúde das enfermeiras em Unidade Básica de Saúde / Maria Cecília Ribeiro. - São Paulo, 2009. $110 \mathrm{p}$.

Dissertação (Mestrado) - Escola de Enfermagem da Universidade de São Paulo.

Orientadora: Prof $^{\mathrm{a}}$ Dr $^{\mathrm{a}}$ Rosa Maria Serpa Godoy da Fonseca.

1. Competência profissional 2. Prática profissional (ética)

3. Atitudes do pessoal de saúde (ética) 4. Enfermeiras I. Título. 


\title{
FOLHA DE APROVAÇÃO
}

\author{
Nome: Maria Cecilia Ribeiro
}

Título: Competência Profissional: A dimensão do Saber-Ser Ético Profissional nas práticas de saúde das enfermeiras em Unidade Básica de Saúde.

Dissertação apresentada à Escola de Enfermagem da Universidade de São Paulo, para obtenção do título de Mestre em Enfermagem.

Aprovado em:

\section{Banca Examinadora}

Prof ${ }^{\mathrm{a}}$. Dra.

Julgamento:

Prof ${ }^{a}$. Dra.

Julgamento:

Prof $^{\mathrm{a}}$. Dra.

Julgamento:
Instituição:

Assinatura:

Instituição:

Assinatura:

Instituição:

Assinatura: 


\section{Agradecimentos}

À minha orientadora, Prof ${ }^{a}$. Dr ${ }^{a}$. Rosa Maria Godoy Serpa da Fonseca, pela paciência, respeito e confiança com que me conduziu neste processo e pelos ensinamentos que sempre me proporciona.

Às Prof ${ }^{a}$ s.Dr ${ }^{a}$ s. Emiko Yoshikawa Egry e Eunice Nakamura pelas valiosas contribuições por ocasião do exame de qualificação e nas fases seguintes da pesquisa.

A todo corpo docente da Escola de Enfermagem da Universidade de São Paulo.

Ao corpo técnico-administrativo da Escola de Enfermagem da Universidade de São Paulo, em especial à Silvana Maximiano e Terezinha pela afetuosa prontidão com que nos atende.

Aos profissionais da Biblioteca "Wanda de Aguiar Horta" da EEUSP, em especial à bibliotecária Juliana Akie Takahashi.

Aos profissionais da UBS Jardim Comercial, Jardim Manacá e Parque do Engenho II pela generosidade em conceder as entrevistas.

À Paula Hino pela parceria no desenvolvimento da pesquisa.

Ao Carlos Spezia, pela presteza na revisão de português e elaboração do abstract.

À Solange Baraldi pela amizade e incentivo para iniciar e prosseguir nesse caminho.

À Cláudia Marques, Maria Bonifácio, Marta Peralba, Mônica Durães e Maíra Apostólico que muito contribuem para meu aprendizado no campo institucional e pessoal.

À minha amada família pelo incentivo, apesar de silencioso constante.

À Teresa, minha amada e companheira, pessoa com quem apreendi que a paciência e calma são as grandes virtudes para vencer qualquer obstáculo. 


\section{METRÓPOLE}

"É SANGUE MESMO, NÃO É MERTIOLATE"

E TODOS QUEREM VER

E COMENTAR A NOVIDADE.

"É TÃO EMOCIONANTE UM ACIDENTE DE VERDADE"

ESTÃO TODOS SATISFEITOS

COM O SUCESSO DO DESASTRE:

VAI PASSAR NA TELEVISÃO

"POR GENTILEZA, AGUARDE UM MOMENTO.

SEM CARTEIRINHA NÃO TEM ATENDIMENTO -

CARTEIRA DE TRABALHO ASSINADA, SIM SENHOR.

OLHA O TUMULTO: FAÇAM FILA POR FAVOR.

TODOS COM A DOCUMENTAÇÃO.

QUEM NÃO TEM SENHA NÃO TEM LUGAR MARCADO.

EU SINTO MUITO MAS JÁ PASSA DO HORÁRIO.

ENTENDO SEU PROBLEMA MAS NÃO POSSO RESOLVER:

É CONTRA O REGULAMENTO, ESTÁ BEM AQUI, PODE VER.

ORDENS SÃO ORDENS.

EM TODO CASO JÁ TEMOS SUA FICHA.

SÓ FALTA O RECIBO COMPR OVANDO RESIDÊNCIA.

PRA LIMPAR TODO ESSE SANGUE, CHAMEI A FAXINEIRA -

E AGORA EU VOU INDO SENÃO PERCO A NOVELA

E EU NÃO QUERO FICAR NA MÃO.”

RENATO RUSSO 
Ribeiro MC. Competência Profissional: A Dimensão do saber-ser ético-profissional nas práticas de saúde das enfermeiras em Unidade Básica de Saúde. [dissertação]. São Paulo: Escola de Enfermagem, Universidade de São Paulo; 2009.

\section{RESUMO}

A complexidade da dimensão do saber-ser ético-profissional reside na questão de lidar com elementos como emoção e subjetividade em relação aos conhecimentos e habilidades, para compreender a prática do cuidar, onde o que se valoriza é a objetividade e a racionalidade. Tendo como pressuposto que a competência profissional se expressa nas práticas desenvolvidas no cotidiano, um dos caminhos indicados para observá-la é a própria prática profissional. Assim, o desenvolvimento deste estudo buscou investigar como se expressa o saber-ser ético-profissional das enfermeiras nas práticas profissionais em uma unidade básica de saúde. Além disso, buscou conhecer as situações do cotidiano onde são identificados elementos relacionados a essa dimensão da competência profissional e também verificar a aplicabilidade dos marcadores do saber-ser ético-profissional estabelecidos para os auxiliares de enfermagem nas práticas das enfermeiras. Tratou-se de um estudo qualitativo e exploratório cujo marco teórico-metodológico foi o materialismo histórico e dialético. O método para interpretação dos discursos referenciou-se na análise de conteúdo, tendo a apresentação dos depoimentos seguido a proposta metodológica de Bourdieu. A análise dos dados teve como referencial os marcadores do saberser ético profissional dos auxiliares de enfermagem elaborados anteriormente. Compôs a fonte de material empírico o conjunto de quinze entrevistas semiestruturadas realizadas com enfermeiras das unidades básicas de saúde. Os resultados explicitaram que: os valores emergentes das situações apresentadas pelas enfermeiras são similares aos dos auxiliares de enfermagem; os marcadores do saber-ser ético-profissional dos auxiliares de enfermagem apresentam potencialidade para representar o saber-ser ético-profissional das enfermeiras da unidade básica de saúde e; do total de oito marcadores, cinco estiveram mais evidentes nas situações analisadas. Conclui-se que há similaridades dos valores e marcadores que regem tanto a prática de auxiliares de enfermagem quanto de enfermeiras, o que podem ser entendido como um fator positivo, uma vez que os sujeitos das pesquisas representam duas categorias de uma mesma profissão. Outro aspecto importante é que os valores e marcadores identificados denotam potencialidade para virem a ser considerados referências para o desenvolvimento da competência profissional na dimensão do saber-ser ético-profissional nos processos educativos dos profissionais de enfermagem. Entende-se que pautar a discussão sobre a dimensão do saber-ser ético-profissional nos espaços onde acontecem as práticas de saúde e os processos educativos da enfermagem, é primordial para a construção de práticas de cuidado que favoreçam não só a transformação dos sujeitos (profissionais e usuários) envolvidos, mas o enfrentamento dos problemas de saúde na perspectiva do processo de saúde-doença numa visão histórica e socialmente determinada.

PALAVRAS-CHAVE: Competência profissional. Prática profissional (ética). Atitudes do pessoal de saúde (ética). Enfermeiras. 
Ribeiro MC. Professional Competence: The ethical Professional learn to be dimension on the health practices of nurses from Health Basic Units [dissertation]. São Paulo: Nursing School, University of São Paulo; 2009.

\begin{abstract}
The complexity of the dimension of the ethical Professional learn to be resides on the matter of dealing with elements such as emotion and subjectivity in relation to knowledge and abilities to understand the care practice, where the objectiveness and rationality are valued. Having assumed that the Professional competence is expressed during the everyday tasks, one of the possible ways of observing it is the professional practice itself. Thus the development of this study aimed at investigating how the ethical-professional learn to be is expressed from the professional practices of the nurses of a Health Basic Unit. Besides that the study also tried to know the quotidian situations where elements related to that professional competence dimension can be identified and to verify the applicability of the ethical-professional learn to be established for the nursing auxiliaries in the nurses' practices. The study was qualitative and explorative which theoretical-methodological mark was the historical and dialectic materialism. The speech interpretation methods had as reference the content analysis and the presentation of the affidavits followed the methodological proposal from Bourdieu. The data analysis had as reference the ethical-professional learn to be from the nursing auxiliaries indicators previously elaborated. The source of empirical material was composed of fifteen semi-structured interviews done with nurses from basic health units. The results have shown that: the emerging values from the situations presented by the nurses are similar to the nursing auxiliaries', the ethical-professional learn to be from the nursing auxiliaries have the potential to represent the nurses' ethical-professional learn to be from the basic health units. Out of eight indicators, five were more evident in the analyzed situations. It is possible to conclude that there are similarities of values and indicators which conduct both the nurses' and nursing auxiliaries' practices; this can be understood as a 'positive factor as the research subjects represent two categories from the same profession. Another important aspect is that the identified values and indicators denote potentiality to become references for the development of professional competencies on the ethical-professional learn to be dimension in the educative process of the nursing professionals. It is understood that basing the discussion on the dimension of the ethical-professional learn to be, within the spaces where health practices and nursing educative process take place, is fundamental to the building up of care practices which favor not only the transformation of involved subjects (professionals and users), but also facing health problems in the perspective of the health-sickness process upon a historically and socially determined vision.
\end{abstract}

Key words: Professional competence, Ethical-professional learn to be. Values. Attitudes. 


\section{LISTA DE ILUSTRAÇÕES}

Figura 1 - Supervisão de Área de Saúde de Campo Limpo e respectivos distritos administrativos

Figura 2 - Pirâmide populacional da Subprefeitura de Campo Limpo

Quadro 1 - Equipamentos de Saúde da Subprefeitura de Campo Limpo

Figura 3 - Unidades Básicas de Saúde localizadas no Distrito de Capão Redondo 


\section{LISTA DE SIGLAS}

$\begin{array}{ll}\text { COFEN } & \text { Conselho Federal de enfermagem } \\ \text { ESP } & \text { Estratégia Saúde da Família } \\ \text { Profae } & \begin{array}{l}\text { Projeto de Profissionalização dos Trabalhadores da } \\ \text { Área de Enfermagem }\end{array} \\ \text { PSF } & \text { Programa Saúde da Família } \\ \text { SCC } & \text { Sistema de Certificação de Competências } \\ \text { SUS } & \text { Sistema Único de Saúde } \\ \text { UBS } & \text { Unidade Básica de Saúde } \\ \text { UNASP } & \text { Centro Universitário Adventista de São Paulo } \\ \text { UNESCO } & \begin{array}{l}\text { Organização das Nações Unidas para a educação, a } \\ \text { ciência e a cultura }\end{array}\end{array}$




\section{SUMÁRIO}

\section{Apresentação}

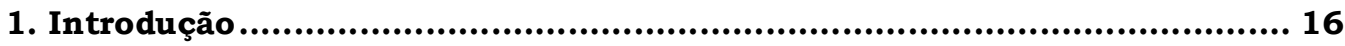

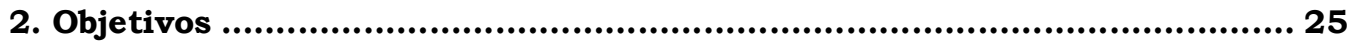

3. Referencial teórico-metodológico ….................................................... 26

$3.1 \mathrm{O}$ caminho histórico-social dos valores e das virtudes ............................ 26

3.2 Enfermagem - Ética e moral ……................................................... 35

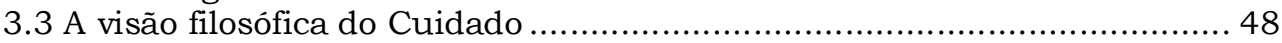

3.4 Resgate histórico do Cuidado ......................................................... 35

3.5 Enfermagem - a essência no cuidar …................................................ 56

3.6 A Atenção Básica e a estratégia Saúde da Família....................................... 56

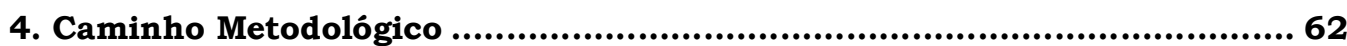

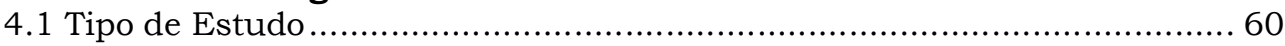

4.2 Local de coleta e fonte de dados empíricos............................................ 62

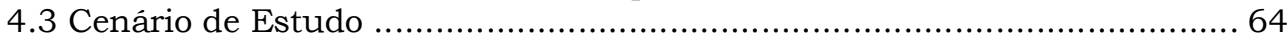

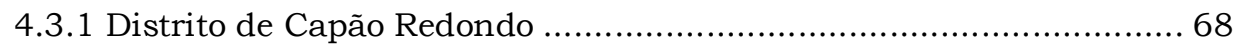

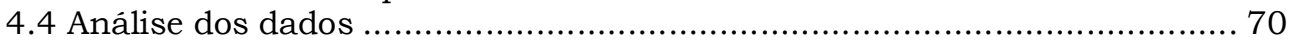

5. Resultados e Discussão .........................................................................73 73 5.1 Compreender o âmbito das ações da enfermagem na produção de serviço de

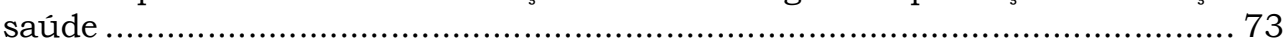

5.2 Mobilizar saberes para avaliar contextos e tomar decisões ....................... 78

5.3 Interagir com o usuário e seus familiares, demosntrando atenção às várias formas de manifestação de suas necessidades e demandas ............................ 81 5.4 Perceber, compreender e respeitar-se como cidadão e como trabalhador de

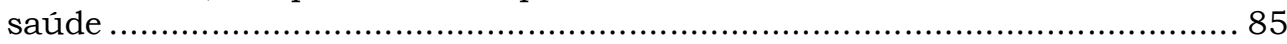

5.5 Demonstrar responsabilidade para com usuários e equipe nas situações de trabalho ......................................................................................... 86 5.6 Interagir com a equipe de trabalho de acordo com os valores que regem o trabalho da enfermagem ….................................................................... 88

5.7 Respeitar os direitos dos usuários como cidadãos .................................. 90 5.8 Compreender e posicionar-se frente às condições de trabalho existentes nas instituições ............................................................................... 93

6. Considerações Finais ....................................................................... 95

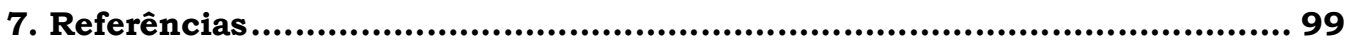

APÊNDICE 1 - Caracterização sócio-econômica dos participantes ...................... 107

APÊNDICE 2 - Roteiro de entrevista individual com a Equipe de Saúde da Família

APÊNDICE 3 - Termo de Consentimento Livre e Esclarecido 107

ANEXO 1 - Marcadores do saber-ser ético-profissional do Auxiliar de Enfermagem

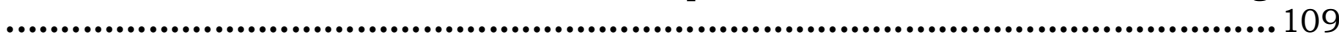

ANEXO 2 - Parecer do Comitê de Ética da Escola de Enfermagem da USP ...... 1070 


\section{Apresentação}

O meu interesse em conhecer como se expressa a dimensão do saber-ser ético profissional nas práticas dos profissionais de saúde de nivel superior de enfermagem originou-se durante a execução das atividades assistenciais desenvolvidas na unidade de terapia intensiva, no período de 1995 a 2001.

Durante as atividades assistências e gerencias executadas ao longo desse período, chamou-me a atenção o distanciamento dos profissionais de enfermagem em relação aos usuários durante o cuidado prestado e as diferentes atitudes adotadas por enfermeiras em situações previstas ou imprevistas semelhantes.

No cotidiano do trabalho na unidade de terapia intensiva, o cuidado de enfermagem era prestado de forma mecanizada, privilegiando instrumentos, equipamentos e materiais a serem utilizados. Era raro o reconhecimento do ser humano que recebia o cuidado, uma vez que o cuidado era prestado em função da terapêutica médica. Durante a assistência prestada, a vontade do paciente era reprimida ou desconsiderada e, muitas vezes, não the era dada opção de escolha. Esse fenômeno ocorre porque

\footnotetext{
Em nossa estrutura profissional restringir a liberdade de alguém talvez não seja um problema, pois, na maioria das vezes, o que se pretende obter por meio do cuidado é a recuperação da saúde e, na concepção de saúde mecanicista, na qual o sistema vigente apóia-se, o desenvolvimento do ser humano ou o resgate de sua condição humana mais ampla não tem necessariamente tangência com a saúde (Domingues, 2004, p.3).
}

O envolvimento do cuidador com o paciente e a família também não ocorria, não havia por parte da equipe de enfermagem a preocupação de prestar a assistência mais humanizada. Segundo 
Waldow (2002), muitos procedimentos e tratamentos são viabilizados por máquinas e os profissionais, por sua vez, apenas necessitam instalá-las e checá-las, o que propicia o negligenciamento e por vezes o abandono das demais dimensões do cuidar como: tocar, conversar, informar, entre outros. Observava-se uma preocupação com o desempenho das ações, ou seja, a equipe de enfermagem não cuidava e sim executava ações e procedimentos, tendo sua prática centrada em tarefas.

Observando essa forma de prestar o cuidado e sentindo dificuldades em estabelecer a maneira e a importância como isso era compreendido pelos enfermeiros, comecei a questionar sobre as prováveis explicações para o distanciamento dos profissionais de enfermagem e as diferentes atitudes assumidas pelas enfermeiras em situações similares.

No ano de 2001, tive a oportunidade de modificar minha área de atuação profissional, ingressando na Secretaria de Gestão do Trabalho e da Educação na Saúde do Ministério da Saúde como consultora técnica do Projeto de Profissionalização dos Trabalhadores da Área de Enfermagem (Profae). Dentre as ações executadas pelo Profae estão a qualificação de auxiliares de enfermagem e a elaboração de uma metodologia avaliativa do Sistema de Certificação de Competências (SCC).

Trabalhando na formulação, construção e implementação da validação da metodologia de avaliação de competências do SCC/Profae, deparei-me novamente com a necessidade de buscar respostas às inquietações a respeito do distanciamento da equipe de enfermagem do paciente, durante a prestação de cuidados. O ressurgimento dos incômodos ocorreu durante a participação na pesquisa "As práticas de enfermagem e as competências do saber- 
ser", cuja finalidade era subsidiar a elaboração de instrumentos avaliativo das competências do saber-ser do Auxiliar de Enfermagem.

A inquietude levou-me a buscar me qualificar cursando como aluna especial disciplinas do Curso de Pós-graduação em Enfermagem - nível de Mestrado - Área de Concentração Enfermagem em Saúde Coletiva da Escola de Enfermagem da Universidade de São Paulo. Posteriormente, ao ingressar como aluna regular, pude transformar meu incômodo em uma proposta de investigação fundamentada cientificamente, de interesse para intervenção nas práticas de saúde, além de constituir uma etapa importante da minha formação profissional. 


\section{Introdução}

O cuidado constitui a essência humana, sendo o suporte real da criatividade, da liberdade e da inteligência. Possibilita perceber a existência dos outros, além de qualificar nosso relacionamento com os outros e permitir que o outro desenvolva sua autonomia (Fonseca, 2008).

Para Boff (2005, p.29)

O cuidado somente surge quando a existência de alguém tem importância para mim. Passo então a dedicar-me a ele: disponho-me a participar de seu destino, de suas buscas de seus sofrimentos e de seus sucessos, enfim, de sua vida.

Segundo o autor, cuidar é mais que um "ato" é uma atitude, logo, abrange mais que um momento de atenção, de zelo e de desvelo. Representa uma atitude de ocupação, de preocupação, de responsabilização e de envolvimento. O cuidado não é a relação sujeito-objeto, mas a relação sujeito-sujeito (Boff, 2001).

No cuidado encontra-se o ethos fundamental do humano. Ethos, em grego, significa "a toca do animal ou a casa humana; o conjunto de principios que regem transculturalmente o comportamento humano para que seja humano no sentido de ser consciente, livre e responsável; o ethos constrói pessoal e socialmente o habitat humano" (Boff, 2001, p.27).

Boff (2001) afirma que o ethos expressa o conjunto de valores, princípios e inspirações que dão origem a atos e atitudes do indivíduo o que faculta identificamos os seus valores e as suas atitudes.

Waldow (2004) considera primordial aplicar o cuidado autêntico; essa dimensão do cuidado possibilitaria ao outro cuidar do 
seu próprio ser, rompendo a relação de poder e dependência do agente cuidador em relação ao agente cuidado, predominante nas práticas de enfermagem existentes desde os tempos mais remotos e que perpetuam até os dias atuais.

Sendo o cuidado o ethos da profissão de enfermagem, cabe ressaltar que o cuidado de enfermagem faz parte de um processo de inter-relações entre o cuidador, paciente e família, por meio de ações e atitudes imbuídas de conhecimento científico, acompanhadas em maior ou menor grau de comportamentos que propiciam estas interrelações (Fonseca, 2008).

A característica básica da prática profissional da enfermagem reside na sua capacidade de desenvolver, de forma contínua, o cuidado como intervenção sobre problemas de saúde da população. Tem-se preocupado cada vez mais em compreender o significado desse cuidar, bem como instituí-lo como científico na busca da definição da sua identidade profissional no conjunto das profissões da área da saúde. O processo de trabalho em enfermagem envolve pessoas que cuidam de outras pessoas, responsabilizando-se por minorar o sofrimento alheio, auxiliar na dependência e buscar a autonomia do individuo (Fonseca, 2008).

Ao cuidado, enquanto prática e ação humana, subjazem os valores morais que o permeiam, que constituem o saber ideológico do processo de trabalho da enfermagem. Também quanto à finalidade do processo de trabalho de saúde e de enfermagem - têm sido cada vez mais freqüentes as reflexões em torno dos valores morais que devem permear a atuação da enfermagem (Fonseca, 2008).

Isto porque a nova visão de qualidade da assistência inclui, além de aspectos técnico-institucionais, a humanização do cuidado 
em sua dimensão ética, reconhecendo e valorizando a autonomia das pessoas para assumirem sua própria saúde.

Porém, dentro das instituições de saúde estão sendo produzidas relações de poder de tal modo que o processo saúdedoença perde seu caráter histórico e passa a ser visto como processo exclusivamente biológico, à margem das determinações sociais e desconsiderando que o processo saúde-doença

[...] compõe momentos de um processo maior, que se refere à vida das pessoas, que por sua vez, está intrinsecamente ligada ao potencial que elas têm ao acesso às necessidades para viver a vida, seja a moradia, a alimenta, a educação, a saúde, o lazer, etc (Fracolli, Bertollozi, 2001. p 04.).

Deste modo, a doença é tratada apenas no âmbito da sua existência individual e não como conseqüência da própria forma em que se estabelecem as condições de vivência e sobrevivência (Rosa, 1985).

Contrariando a expectativa de cuidado humanizado, Waldow (2004) constatou que as enfermeiras estão distantes da prestação do cuidado direto ao paciente, o que dificulta a percepção da realidade. O contato com os usuários e familiares ocorre de forma breve e quase exclusivamente para realizar procedimentos pertinentes à sua formação profissional, ao que dita o Código de Ética Profissional, atender alguma solicitação, solucionar algum problema; colher informações ou atender a uma emergência.

Moreira (1998) constatou nos discursos dos sujeitos de sua pesquisa a comparação da relação estabelecida entre paciente e aluno e paciente e enfermeira. Os pacientes relataram que se ressentem da falta de atenção e disponibilidade da enfermeira. 
Segundo Waldow (2004), algumas instituições prosseguem na busca da profissionalização dos valores e das atitudes, com a finalidade de realizar o cuidado através de conhecimentos e habilidades, o que é influenciado pelo positivismo, expresso pelo modelo biomédico e pelos currículos de linha comportamentalista das instituições formadoras.

No estudo desenvolvido por Domingues (2004), é possivel identificar a ênfase concedida ao conhecimento científico e as habilidade através do relato das entrevistadas que apontam haver "uma preocupação relacionada prioritariamente ao ambiente e a estrutura física do setor em detrimento da pessoa. Os valores que predominam, via de regra, são conhecimento científico e habilidade técnica" (Domingues 2005, p.84)

\footnotetext{
É desejável agirmos, de acordo com o que é preconizado na instituição de saúde a que pertencemos, o mesmo se aplica à consonância de nosso agir com as ciências que dão sustentação teórica a nosso exercício profissional. No entanto, não nos parece óbvio nem desejável que estes dois balizadores de nosso exercício profissional substituam nossas opções éticas em relação a nosso agir, profissional ou não (Domingues, 2005, p. 8).
}

Nesse sentido, o cuidado passa a ser apenas ações mecânicas, atomizadas, dirigidas a manter a vida e perdendo-se a noção do todo.

Ocorre que também nos cursos de formação profissional em enfermagem, a atenção é voltada para o ensino do cuidado técnicoinstrumental. Este movimento leva à reprodução das práticas de enfermagem de forma desumanizada se contrapondo a Bobroff (2003), para quem durante o ato de cuidar "é necessário que a outra vertente, além do técnico-instrumental, também esteja presente - o cuidado afetivo-expressivo, como o saber ser". 
Neste sentido Bellato (2003, p. 431) enfatiza que:

[...] também os enfermeiros vêm sendo formados, nas últimas décadas, com um enfoque fundamentado na doença, com uma estruturação ideológica de um saber determinado por uma objetividade tecnicista e com grande ênfase no aparato tecnológico, que desconsidera a subjetividade do sujeito sob seus cuidados. É preciso reconsiderar esse centramento da atividade profissional nos instrumentais técnicos e tecnológicos, dando-lhes seu valor devido como instrumentais do cuidado e não como foco principal deste.

Para Coelho, Fonseca (2005, p. 214):

O modelo biomédico, que sustenta as formações profissionais em saúde, orientado pela racionalidade clínica e seus padrões de normalidade, tem reduzido seres humanos a corpos biológicos, descontextualizados socioculturalmente. Sob este paradigma, a atenção é dirigida a sujeitos individuais em suas unidades morfológicas, impedindo a sintese entre o individual e o coletivo.

Nesta perspectiva, ocorre a redução do espaço do cuidado, uma vez que os sujeitos são desconsiderados em sua multidimensionalidade.

Vale ressaltar que em 1999 a UNESCO - Brasil editou o livro "Educação: um tesouro a descobrir" a partir do Relatório da Conferência Internacional sobre a Educação para o Século XXI, coordenado por Jacques Delors. Esse relatório postulou os quatro pilares da educação: saber-conhecer; saber-fazer; saber-ser e saberconviver. Tais pilares são eixos norteadores de uma proposta de educação que visa a um projeto de vida em comum, incorporando conhecimentos e habilidades às atitudes pessoais e sociais (Delors, 2003).

Para Leonello (2007a), no campo da saúde, especialmente no que se referem à formação profissional, os quatro pilares da educação 
permitem o seguinte entendimento; o saber-conhecer faz referência ao domínio dos instrumentos da dimensão cognitiva. Essa dimensão pressupõe um aprender a aprender de forma continua, uma vez que o processo de aprendizado nunca está finalizado, devendo ser construído ao longo das experiências cotidianas dos indivíduos. $O$ saber-fazer vai além do preparo para a execução da simples tarefas. Envolve a necessidade de articular o preparo técnico às aptidões pessoais e relacionais, que envolve o trabalho em equipe, iniciativa entre outros. Para a autora, o saber-conviver representa o maior desafio da educação, uma vez que a convivência depende da descoberta do outro como sujeito e do trabalho coletivo de projetos comuns. Aliado a isso, existe a necessidade de respeitar os valores de pluralismo, compreensão mútua e paz. Por fim, o saber-ser envolve o comprometimento e o compromisso social do individuo em relação à sua realidade, reconhecendo-se com sujeito capaz de transformar a realidade.

A autora ressalta que:

No campo da saúde, especialmente no que se refere à formação profissional, os quatro pilares da educação permitem compreender que a construção de competências implica articular diferentes saberes para construção de uma prática profissional pautada não somente na aquisição e incorporação de conhecimentos e habilidades, mas também em atitudes pessoais e relacionais que visam à construção de um projeto comum para a transformação da realidade em saúde (Leonello, 2007b, p. 848).

Diante do exposto, observa-se que o Relatório da Conferência Internacional sobre a Educação para o Século XXI traz a preocupação com a formação ampla, isto é, além da instrução técnicainstrumental, estudos têm demonstrado a tentativa de aproximação com essa formação profissional ampliada visando à adequação curricular no sentido de possibilitar formar um profissional mais humanizado. 
Assim, para que a prestação do cuidado seja condizente com as necessidades de saúde da população, faz-se necessário que as enfermeiras articulem as três dimensões da competência profissional: saber-saber, correspondente ao conhecimento; saber-fazer, equivalente às habilidades e o saber-ser, expresso pelos valores e atitudes que inclui, entre outros, o comportamento nas relações sociais de trabalho. É importante salientar que neste estudo a dimensão do saber-conviver está contida na dimensão do saber-ser.

Para o Brasil (2000), a noção de competência está referida ao cuidado, em sua dimensão ética, uma vez que a produção e a prestação dos serviços da saúde têm como características fundamentais o acautelamento dos riscos e o resguardo do direito à saúde com qualidade.

Sabendo que o conceito de competência é polissêmico e que essa polissemia decorre de diferentes visões de mundo, sustentada em matrizes epistemológicas diversas e variando seu significado segundo o autor, setor de produção e país (Marques, 2007), o conceito de competência a ser adotado nessa pesquisa é o elaborado pelo SCC/Profae, que entende competência como a:

\footnotetext{
Capacidade de assumir a responsabilidade do cuidado partindo da concepção de saúde como qualidade de vida, interagindo com o cliente, suas necessidades e escolhas, valorizando sua autonomia para assumir sua própria saúde, e agir mobilizando conhecimentos, habilidades, atitudes e valores requeridos pelas situações (imprevistas ou não) na promoção/produção do cuidado (Brasil, 2000).
}

As competências profissionais são percebidas como condicionantes do contexto econômico, social e político, expressando relações sociais e sendo resultado de negociações entre os interesses dos diferentes atores envolvidos no processo. O desenvolvimento da competência profissional não está restrito a uma perspectiva individualista, uma vez que elas são construídas ao longo da vida 
profissional, que partilha experiências e práticas coletivas; e ainda não se limitam à simples descrição de tarefas em postos de trabalho (Brasil, 2000).

Marques (2007, p. 35) ressalta que:

As competências são contextualizadas, historicamente definidas, individual e coletivamente construídas, desenvolvendo a idéia de competência profissional ampliada (não apenas técnica), pois liga a todo um patrimônio de experiências coletivas.

Diante do exposto, considera-se que a dimensão do saber-ser ético-profissional

[...] se expressa em atitudes de solidariedade, civilidade, compartilhamento, responsabilidade e ética. Esta dimensão incorpora: interagir com o usuário e seu grupo social, com a coletividade e a população; estar atento à linguagem corporal do usuário; respeitar valores; culturas e individualidades ao pensar e propor as práticas da saúde; buscar alternativas frente a situações adversas, com postura ativa; recorrer à equipe de trabalho para solução ou encaminhamento de problemas identificados; compreender a pertinência, a oportunidade e a precisão das ações e dos procedimentos que realiza mediando-se pelos indivíduos, grupos e população a que se refere sua prática profissional; colocar-se em equipe profissional em prol da organização e da qualidade do cuidado de enfermagem; pensar criticamente seus compromissos e responsabilidades como cidadão e trabalhador de saúde (Brasil, 2001).

Numa busca bibliográfica objetivando encontrar a produção científica referente ao saber-ser ético-profissional da enfermagem, constatou-se escassez de resultados, ou seja, essa produção é praticamente inexistente. O resultado da busca bibliográfica também possibilitou identificar que não somente as práticas profissionais privilegiam as competências profissionais aderentes às dimensões do saber-fazer e saber-saber, mas isso ocorre também com a produção do conhecimento.

Desta forma, estudar o saber-ser ético-profissional dos trabalhadores de nivel superior de enfermagem, portanto, significa 
reconhecer a base do trabalho da enfermagem na sua dimensão relacional e humanitária, quais sejam as virtudes, valores e atitudes que embasam a prática profissional. Em outras palavras, para identificar como se expressa o saber-ser ético-profissional com base na prática profissional é necessário criar estratégias que efetivamente consigam compreender características humanas fundamentais para o estabelecimento do processo relacional entre cuidador e cuidado.

Partindo das reflexões anteriormente expostas e tendo como pressuposto que a competência profissional se expressa nas práticas, um dos caminhos mais indicados para observá-las é a própria prática profissional. Assim, este estudo buscou investigar como se expressa o saber-ser ético-profissional das enfermeiras nas práticas profissionais em uma unidade básica de saúde. A complexidade da questão residiu em lidar com elementos como emoção e subjetividade em relação aos conhecimentos e habilidades, para compreender a prática do cuidar, onde o que se valoriza é a objetividade e a racionalidade. 


\section{Objetivos}

\section{Geral}

Identificar como se expressa o saber-ser ético-profissional das enfermeiras nas práticas profissionais em uma unidade básica de saúde.

\section{Especificos}

1. Conhecer situações do cotidiano da prática profissional das enfermeiras em unidade básica de saúde onde possam ser identificados elementos relacionados à dimensão do saber-ser da competência profissional.

2. Verificar a aplicabilidade dos marcadores do saber-ser ético-profissional desenvolvido para o auxiliar de enfermagem nas práticas de enfermagem para as enfermeiras da unidade básica de saúde. 


\section{Referencial teórico-metodológico}

\subsection{O caminho histórico-social dos valores e das virtudes}

A sociedade não pode ser considerada como algo que existe em si e por si, como uma realidade substancial que se sustenta independentemente dos indivíduos que a compõem. Assim, a formação dos valores e das competências relacionais a eles aderentes, na visão do materialismo histórico e dialético, subjaz ao entendimento da sociedade como composta de infra-estrutura e de superestrutura. Para Marx, citado por Egry (1996, p. 34), a infraestrutura constitui a base da econômica, engloba as relações do homem com a natureza e as relações dos homens entre si. A superestrutura é constituída pela estrutura juridico-política, representada pelo Estado e o direito, e pela estrutura ideológica, referentes às formas de consciência social, tais como a religião, as leis, a educação, a literatura, entre outras.

Além de estabelecer entre si relações de produção, os seres humanos estabelecem outros tipos de relação sociais que têm como base a consciência social. Estas relações se formam e se difundem através da educação, instrução e outros meios de informação social.

Marx (1959) citado por Bottomore (1993, p. 27) salienta que:

$\mathrm{Na}$ produção social de sua vida, os homens estabelecem determinadas relações necessárias e independentes de sua vontade, relações de produção que correspondem a uma determinada fase do desenvolvimento de suas forças produtivas materiais. O conjunto dessas relações de produção forma a estrutura econômica da sociedade, a base real sobre a qual se ergue a superestrutura jurídica e política e à qual corresponde determinadas formas de consciência social. O modo de produção da vida social, política e intelectual em geral. 
A superestrutura interage dialeticamente com a base da sociedade sendo determinada por ela e, em certa medida, determinando-a. Nessa relação - base e superestrutura - a "determinação" pelo econômico, especialmente no modo de produção capitalista, difere da simples "causação", tratando-se de mais do que uma simples relação de causa e efeito (Egry, 1996).

Para a compreensão da superestrutura é de fundamental importância o entendimento de consciência social. A consciência social não se realiza fora da sociedade ou independentemente dela, mas sim assimilando tudo o que foi construído pela humanidade no seu percurso histórico. A consciência social pode ser definida como uma qualidade nova que caracteriza o reflexo mais profundo do indivíduo social, entendido nesse estudo como o indivíduo que vive em sociedade, é parte integrante de um determinado grupo social e portador de um conteúdo ideológico que exprime a consciência social desse grupo. A consciência social não pode ser entendida como a somatória das concepções idéias e valores inerentes a diversos indivíduos (Fonseca, 2006).

Segundo Egry (1996, p.34) a consciência social é:

A categoria do materialismo [histórico e dialético] utilizada
para designar a vida espiritual da sociedade em que se
reflete o ser social. Não se trata da consciência duma certa
pessoa ou dum determinado indivíduo, mas, sim, das
concepções, idéias e noções características para toda a
sociedade ou para determinado grupo social [...].

Neste sentido, a consciência social reflete não somente o ser no momento dado, mas por ser histórica, inclui os valores acumulados pelas gerações anteriores, que são transmitidos através das artes, religião, ciência e outra forma de manifestação como as idéias, os conceitos e as aspirações que além de se influenciarem mutuamente, se encontram em permanente transformação. Apesar de ser única, a consciência social se manifesta dialeticamente nas dimensões da 
realidade objetiva, de diferentes formas: consciência individual, relativa à consciência de grupos sociais e a consciência geral, relacionada às formas de pensamento, imagens e conceitos em que toda a sociedade reflete o seu ser, as suas contradições entre outros (Fonseca, 2006).

Os aspectos internos mais profundos da consciência social, por meio dos quais o ser social interpreta os fatos e acontecimentos da vida em sociedade, referem-se à ideologia. Esta se constitui num sistema organizado de idéias e doutrinas sobre a vida que, além de interpretar os fatos, infiltra-se no ser social, exprimindo interesses e necessidades fundamentais do conjunto social ao qual ele pertence. (Fonseca, 2006)

Chauí (2001, p 41), explica o conceito de ideologia com sendo

O conjunto de representações (idéias, valores) e de normas ou regras de conduta que indicam ou prescrevem aos membros da sociedade o que devem pensar e como devem pensar, o que devem valorizar e como devem valorizar, o que devem sentir e como devem sentir, o que devem fazer e como devem fazer.

A consciência social se manifesta através do sistema políticojurídico referente ao Estado e seus órgãos legislativos e administrativos, ainda fazem parte desta esfera às demais instituições responsáveis pelo sistema educativo, informativo, religioso entre outros. Mesmo não controlando diretamente, o Estado estabelece e normatiza todo o sistema social, bem como o funcionamento das instituições responsáveis pela reprodução e veiculação da ideologia dominante. Além do sistema político-jurídico, existem as demais formas de manifestação da consciência social como a arte, a ciência, a moral e a própria filosofia. A consciência moral, como as demais formas de manifestação da consciência social, é historicamente determinada e encontra-se em constante transformação. Nas sociedades de classes, o sistema moral 
dominante é o da classe dominante, difundido e regulado por seus aparelhos ideológicos que incluem os aparelhos ideológicos do Estado (Fonseca, 2006).

Chauí (2000, p. 147) considera que:

A consciência moral (a pessoa) e a consciência política (o cidadão) formam-se pelas relações entre as vivências do eu e os valores e as instituições de sua sociedade ou de sua cultura. São as maneiras pelas quais nos relacionamos com os outros por meio de comportamentos e de práticas determinados pelos códigos morais (que definem deveres, obrigações, virtudes) e politicos (que definem direitos, deveres e instituições coletivas públicas), a partir do modo como uma cultura e uma sociedade determinadas definem o bem e o mal, o justo e o injusto, o legítimo e o ilegitimo, o legal e o ilegal, o privado e o público. O eu é uma vivência e uma experiência que se realiza por comportamentos; a pessoa e o cidadão são a consciência como agente (moral e político), como práxis.

Vázquez entende consciência moral como:

A capacidade de interiorizar as normas ou regras de ação estabelecidas pela comunidade e de atuar de acordo com elas. A consciência moral é, por um lado, a consciência do fim desejado, dos meios adequados para realizá-los e do resultado possivel; mas é, ao mesmo tempo, decisão de realizar o fim escolhido, pois a sua execução se apresenta como uma exigência ou um dever (Vázquez, 2007, p.78).

O autor assinala que a consciência moral na forma que a conhecemos é o resultado de um longo processo de desenvolvimento da humanidade. Ela conserva desde sua origem um caráter social, uma vez que, em sua interioridade - da consciência moral - o sujeito não escuta somente a sua própria voz, mais também a voz da sociedade que lhe proporcionou os principios e as normas morais. (Vázquez, 2007). 
Chauí (2000, p. 433) assinala que:

\begin{abstract}
A consciência moral manifesta-se, antes de tudo, na capacidade para deliberar diante de alternativas possiveis, decidindo e escolhendo uma delas antes de lançar-se na ação. Tem a capacidade para avaliar e pesar as motivações pessoais, as exigências feitas pela situação, as conseqüencias para si e para os outros, a conformidade entre meios e fins (empregar meios imorais para alcançar fins morais é impossivel), a obrigação de respeitar o estabelecido ou de transgredi-lo (se o estabelecido for imoral ou injusto).
\end{abstract}

Nesse sentido, o sujeito certamente age de acordo com o ditame da sua consciência moral, mas esta, por sua vez, dita somente aquilo que concorda com os princípios, valores e normas de uma moral efetiva e vigente. Portanto, como destaca Vázquez (2007), o comportamento moral é tanto o comportamento do indivíduo como dos grupos sociais humanos, cujas ações têm caráter coletivo, mas deliberado, livre e consciente. Contudo, mesmo quando se trata da conduta de um indivíduo, não estamos diante de um comportamento rigorosamente individual que afete somente o interesse do agente do ato moral, essa conduta afetará a toda sociedade.

Todo ato moral inclui a necessidade de escolher entre vários atos possiveis. Essa escolha deve basear-se, por sua vez, numa preferência. $\mathrm{O}$ individuo opta em agir de forma $x$ por preferir suas conseqüências a $y$ ou $z$. A escolha por $x$ é preferivel por se apresenta como um comportamento mais digno, mais elevado moralmente, ou seja, mais valioso. As opções $y$ ou $z$ são ignoradas porque se apresentam como atos de menor valor ou com um valor moral negativo. (Vázquez, 2007). 
Heller (1992, p. 14) salienta que:

A heterogeneidade da realidade pode dificultar extraordinariamente, em alguns casos, a decisão acerca de qual é a escolha que, entre as alternativas dadas, dispõem de maior conteúdo valioso; essa decisão - na medida em que é necessária - nem sempre se pode tomar independentemente da concreta pessoa que a pratica.

Vázquez (2007, p.189) afirma que "a consciência moral efetiva é sempre a consciência de um homem concreto individual, mas, por isso mesmo, de um homem que é essencialmente social".

Para se guiarem nas relações entre si e para com a sociedade, na vida pessoal e social, os homens possuem a moral, que se refere a um sistema organizado de concepções, princípios e normas, assim como de sentimentos e estados de ânimo (Fonseca, 2008).

A moral se estabelece a partir de valores que são os princípios que fundamentam a consciência humana. Heller (1992, p.4) define valores como "tudo aquilo que faz parte do ser genético do homem e contribui, direta ou mediatamente, para a explicação desse ser genético".

Os valores estão presentes em todas as religiões, filosofias e sociedades, independentemente de raça, sexo ou cultura. São inerentes à condição humana e à relação entre os sujeitos. Além de dignificarem a conduta humana, ampliam a capacidade de percepção do ser como ser de consciência social, consciência essa formada no percurso da sua existência. Corroborando com o exposto, Vázquez (2007) destaca que os valores existem para o sujeito, entendido com um ser social, não como um mero indivíduo. É o homem, como ser histórico-social e com suas atitudes, que cria os valores e os bens nos quais se encarnam. Os valores são, pois, criações humanas e só existem e se realizam no homem e pelo homem. 
Os valores têm no pensamento e nos sentimentos sua manifestação perceptível e aferivel. Quando exercitados, possibilitam a convivência, enaltecendo a condição humana e podendo minimizar preconceitos, desigualdades, iniqüidades.

A virtude (do latim, virtus, palavra derivada de vir, homem, varão) conforme afirma Vázquéz (2007, p.214) “é a capacidade ou potência particular do homem e, no sentido relacionado à moral pode ser entendida com a capacidade ou potência moral."

Para Compte-Sponville (1999), a virtude pode ser entendida como uma força que leva o indivíduo a agir ou que pode levá-lo a agir. Assim, a virtude do homem é querer agir humanamente, como a virtude de uma faca é corta e a de um remédio é curar. Ainda conforme o autor, esses exemplos que vêem do grego refletem o essencial, ou seja, a virtude é o poder, mas um poder específico. A virtude de um ser é o que constitui o seu valor, ou em outras palavras, sua própria essência: a boa faca é a que corta bem e o bom remédio é o que cura. No sentido geral, as virtudes são independentes do uso que delas se faz, como do fim que visam ou servem. "A virtude ou as virtudes são os valores morais vividos em ato" (Fonseca, 2008).

Neste sentido, a virtude supõe uma disposição estável ou uniforme de comportar-se moralmente. Por isso se relaciona de perto com o valor moral, envolvendo assim a compreensão do valor em que se fundam as normas morais que guiam e orientam a execução do ato moral. Ao mesmo tempo a virtude supõe a decisão para superar os obstáculos que se interponham a realização do ato moral (Vázquez, 2007).

A visão materialista histórica concebe que é no percurso social que o indivíduo vai aprender, desenvolver e reproduzir os valores e as virtudes. As virtudes seriam, então, igualmente, produtos ou 
construções sociais e embasariam a vida humana a partir da constituição da sociedade, num processo fortemente influenciado pela superestrutura social (Fonseca, 2008).

O sujeito se torna virtuoso quando contribui através de suas virtudes com a realização da moral, não mediante atos esporádicos ou privilegiados, mas com atos cotidianos e repetitivos que decorrem de uma disposição permanente e estável (Vázquez, 2007).

A formação de valores é uma atividade que se realiza como parte do processo afetivo de formação da personalidade e resulta da cotidianidade, da interação entre os seres humanos para que seja alcançada sua compreensão acerca dos valores que se pretende formar, que sejam significativos para o sujeito do processo (Forcella et al, 2005).

Domingues (2004, p. 09) considera que:

O sentimento da vida de um homem é dado pelos valores e, por meio deles o homem vive plenamente sua condição humana, é possivel observar que o homem exerce uma atitude axiológica diante de tudo que o cerca, sendo com isso capaz de julgar se uma coisa é boa ou ruim, agradável ou desagradável, justa ou injusta.

Ocorre que segundo Forcella et al (2005, p. 54):

[...] as grandes transformações da humanidade e os problemas atuais têm impregnado a vida com anti-valores ou contra-valores (o contrario de valores) que levam à cultura e a necessidade de acumulação de riquezas, do individualismo e da competitividade desenfreada e a qualquer preço.

Por conseqüência, os valores e as virtudes deixam de ser vistos como os verdadeiros pilares das relações humanas se tornando inatingiveis, utópicos ou mesmo vazios de conteúdo. Exemplos de contra-valores são o egoísmo, o individualismo, a competição desmedida, o não reconhecimento do outro na relação, o exercício do 
poder hierarquizado tendo como fito a subalternização do outro através do poder pelo saber, pela posição social entre outros (Forcella et al, 2005).

Para Domingues (2004, p.07)

O modo de vida contemporâneo baseado, especialmente, em valores pragmáticos e mercantilistas, parece nos impor um cotidiano que, na maioria das vezes, se incompatibiliza com reflexões relativas a nosso agir. Raramente pensamos e optamos de modo consciente pela finalidade dos nossos atos.

A autora considera ainda que o conceito de um determinado valor não implica compreender nem agir, de acordo com ele, o conhecimento do valor exige uma experiência e, conseqüentemente, uma resposta, faz com que se assuma diante dele uma escolha, mas nunca uma indiferença. Esta indiferença seria a própria negação do valor pois, dessa forma, os valores teriam como característica a polaridade, nunca um valor é positivo ou negativo ao mesmo tempo. Em decorrência da polaridade, não há valor único (Domingues, 2004).

Virtudes e valores podem ser ensinados mais pelo exemplo do que pelos livros, por melhores que eles possam ser. Assim, um tratado das virtudes serve de base para a compreensão do que deveríamos fazer, ser ou viver, além de medir com isso, pelo menos intelectualmente, a distância que nos separa disso. Só se ensina uma virtude praticando-a, não sendo possível abordá-la, mesmo que pedagogicamente, de maneira teórica e desprovida do lastro da realidade (Forcella et al, 2005).

Para o mundo do trabalho, as virtudes listadas por ComteSponville, (1999) no "Pequeno Tratado das Grandes Virtudes", são: polidez; fidelidade; prudência; temperança; coragem; justiça; 
generosidade; compaixão; misericórdia; gratidão; humildade; simplicidade; tolerância; pureza; doçura; boa fé; humor e amor.

Forcella et al (2005), tomando como referência Comte-Sponville e outros autores apontou em seu estudo valores que considera importantes para as relações humanas no trabalho, tais como: compaixão; respeito; tolerância, humildade; compreensão; união; responsabilidade; solidariedade; honestidade; bondade generosidade e lealdade. Esses valores e virtudes indicados pelos autores são essenciais e podem resultar em competências relacionais, principalmente em se tratando de práticas profissionais de enfermagem cujo fazer implica na relação entre sujeitos através do cuidado.

A prática dos valores e das virtudes pode levar ao caminho do auto-conhecimento e da auto-realização mediante o desenvolvimento integrado da personalidade e da espiritualidade, independente da religião, seita, credo ou crença política; ao incentivo à cooperação, criatividade, respeito às diferenças e o amor pelos seres humanos e pela natureza; a libertar as pessoas do medo e da culpa construídos social e historicamente, a mostrar que a liberdade e a felicidade só são alcançadas quando o ser humano for colocado no centro da vida e à prática profissional competente e aderente aos princípios éticos que regem a profissão (Forcella et al, 2005).

\subsection{Enfermagem - Ética e moral}

A ética é uma parte da filosofia que busca refletir sobre o comportamento humano, sobe o ponto de vista das noções de bem e mal de justo e injusto, abrangendo as normas morais e jurídicas. Para Vázquéz (2007) ética é a teoria ou ciência do comportamento 
moral dos homens em sociedade. Ao trazer que a ética não cria a moral, o autor ressalta que:

Toda moral supõe determinados princípios, normas ou regras de comportamento, não é a ética que os estabelece num determinado espaço (comunidade). A ética depara com uma experiência histórico-social no terreno moral, ou seja, com uma série de práticas morais em vigor e, partindo delas, procura determinar a essência da moral, sua origem, as condições objetivas e subjetivas dos juízos morais, os critérios de justificação destes juízos e o princípio que rege a mudança e a sucessão de diferentes sistemas morais (Vázquéz, 2007, p.22).

Atualmente as palavras ética e moral se relacionam de uma forma que não tinham em suas origens etimológicas. Ética vem do grego ethos, que significa analogicamente "modo de ser" ou "caráter" enquanto forma de vida também adquirida ou conquistada pelo homem. Moral vem do latim mos ou mores "costume" ou "costumes", no sentido do conjunto de normas ou regras adquiridas por hábito (Vazquez, 2007).

A moral se refere, assim, ao comportamento adquirido ou modo de ser conquistado pelo homem, que são aceitos e reconhecidos em uma sociedade ou grupo social. Portanto, ethos e mos, costume e caráter, assentam-se num mesmo modo de comportamento que não corresponde a uma disposição natural, porém que é adquirido ou conquistado por hábito (Vázqués, 2007).

Vázquéz (2007, p.37) conceitua moral como "conjunto de normas e regras destinadas a regular as relações dos indivíduos numa dada comunidade social, o seu significado, função e validade não pode deixar de variar historicamente nas diferentes sociedades".

Diante dos conflitos ou das questões complexas, é que percebemos os limites das respostas oferecidas pela moral e a necessidade de problematizar essas respostas, verificando a 
consistência de seus fundamentos. É nesse contexto que surge a ética, buscando a reflexão crítica em relação à consciência e a coerência dos valores que norteiam as ações, para que tenham significado autêntico nas relações (Steinberg, 2005).

Steinberg (2005) destaca o movimento dialético entre a moral e a ética ao considerar que:

A ética serve, portanto, para verificar a coerência entre a prática e principios, além de questionar, reformular ou fundamentar os valores e as normas componentes de uma moral, sem ser em si mesma, normativa. Entre a moral e a ética há um constante movimento dialético, que vai da ação para a reflexão sobre o seu sentido e seus fundamentos. Da reflexão retorna à ação, revigorada e transformada (Steinberg, 2005, p. 50).

Embora, como vimos anteriormente, ética e moral tenham a mesma origem etimológica, no percurso da história da humanidade, os conceitos foram tendo significados distintos. A ética é um conceito que, mesmo de forma subjacente, está presente no cotidiano dos indivíduos. Determina uma condição que pode estar relacionada ao ser humano como sujeito de suas ações ou às atividades por ele desenvolvidas durante suas ações cotidianas incluindo-se também o exercício profissional. No campo da enfermagem, a ética e os comportamentos éticos, em especial, estão estreitamente vinculados as práticas e ao cuidado prestado. Contudo prevalece, entre a maioria dos profissionais de enfermagem, o entendimento presente no senso comum, que percebe a ética como um conjunto de normas ou orientações contidas em códigos. Ou seja, para esses profissionais, agir de forma ética é simplesmente cumprir o referido código ético (Freitas, 2007).

As experiências cotidianas e o contexto em que ocorrem as relações interpessoais e o cuidado, seja entre profissionais de distintos campos de atuação, seja entre profissionais, pacientes e 
familiares, são raramente entendidas como fontes geradoras de conflitos. Taffner (2005, p. 32) se opõe a essa situação, apontando que:

Inúmeras situações do cotidiano possuem implicações éticas ou, até mesmo, desencadeiam dilemas éticos e, diante dessas, o enfermeiro necessita ultrapassar o caráter normativo e jurídico do Código de Ética dos Profissionais de Enfermagem para tomar uma decisão.

A autora afirma que ética não se restringe a um conjunto de normas e orientações contidas em códigos e considera ética como uma:

[...] reflexão profunda e rigorosa sobre valores passando de um aprendizado simplista de cumprimento de um regra social para à reflexão sobre ela, acompanhada de opção consciente por assumi-la ou não (Taffner, 2005,p.32).

Para Boff (2003), a ética profissional não pode ser concebida como resultante de um conjunto cristalizado de normas de conduta profissional, mas como uma reflexão crítica sobre a realidade social do trabalho, das atividades profissionais e do agir pautado nos valores da categoria profissional.

Nessa direção, falar de ética, portanto, é falar de valores e virtudes como, entre outros, prudência, autonomia, responsabilidade e respeito.

Quanto às normas éticas e legais, Reale (1995) citado por Freitas (2007, p. 197), comenta que "toda norma ética expressa juízo de valor, ao qual se liga uma obrigação. Isso decorre da necessidade social de garantir a conduta que é declarada permitida, determinada ou proibida." Complementado a afirmação, Vázquez (2007) entende que só é possível abordar o comportamento moral quando o sujeito que assim se comporta é responsável pelos seus atos, o que envolve o pressuposto de que o indivíduo possa ter a opção de escolha entre 
duas ou mais alternativas, para praticar o ato moral, ou seja, para agir conforme a decisão tomada.

Alguns autores afirmam que as normas morais devem ser cumpridas espontaneamente, uma vez que não há aplicação de penalidades a quem não as obedecer. Já as normas legais são revestidas de obrigatoriedade do cumprimento, ou seja, o indivíduo é obrigado obedecê-la. Nesse sentido, salienta que o que caracteriza a norma legal é o fato de ser uma estrutura enunciativa de uma forma de organização ou de conduta que deve ser seguida de maneira objetiva e obrigatória (Freitas, 2007).

A criação de normas legais para o exercício da enfermagem cabe ao Poder Legislativo da União, ou seja, ao Congresso Nacional, como o fez com a vigente Lei $\mathrm{n}^{\circ} 7.498$, de 25 de junho de 1986, que dispõe sobre a regulamentação do exercício da enfermagem e dá outras providências.

Cabe ressaltar que o Conselho Federal de Enfermagem e os Conselhos Regionais de Enfermagem têm competência legislativa para os enfermeiros, técnicos de enfermagem e auxiliares de enfermagem, o que significa que podem elaborar normas relacionadas ao exercício profissional destas categorias profissionais. Isso ocorre por intermédio de resoluções que têm força de lei, embora não o sejam sob o aspecto jurídico, para os profissionais de enfermagem (Freitas, 2007).

Historicamente, embora outras ações jurídicas como leis e decretos tenham influenciado a ordenação para a formação do profissional enfermeiro, somente com o Decreto $n^{\circ} 16.300$, de 31 de dezembro de 1923, foi criada a primeira escola para enfermeiras. Até aquele momento, em relação ao exercício profissional, as enfermeiras estavam na mesma esfera dos massagistas, manicurosos, pedicuros e 
optometristas, pois todos seguiam estritamente as ordens oriundas dos profissionais médicos (Freitas, 2007).

Segundo (Carvalho, 1976) a providência inicial para a regulamentação do exercício profissional de enfermagem no país foi a promulgação do Decreto no 20.109 de 15 de junho de 1931. Em seu Art. $1^{\circ}$, além dispor sobre o ensino de enfermagem no país, tratava do exercício de enfermagem e determinava quais profissionais "poderiam usar o título de enfermeiro diplomado".

No intuito de regulamentar e fiscalizar o exercício da medicina, odontologia, medicina veterinária e das profissões de farmacêutico, parteiras e enfermeiras, em 11 de janeiro de 1932 foi aprovado o Decreto $n^{\circ}$ 20.93. No tocante à enfermagem, o referido Decreto não apontava definições a respeito das atividades que esse profissional deveria desenvolver, mas estabelecia penalidades em casos de faltas graves ou erros de ofício, além de proibir a instalação de consultórios para o atendimento à clientela (Carvalho, 1976).

A Lei $n^{\circ} 775$, de 06 de agosto de 1949, dispunha sobre o ensino da enfermagem no país, porém em seu Art. 21 incluiu a seguinte recomendação referente ao exercício profissional da enfermagem "as instituições hospitalares, públicas ou privadas, decorridos sete anos após a publicação desta lei, não poderão contratar, para a direção de seus serviços de enfermagem, se não enfermeiros diplomados" (Freitas, 2007). As lideres da enfermagem utilizaram esse preceito legal por décadas para regularizar a situação dos serviços de enfermagem hospitalares.

Somente onze anos depois, em 17 de setembro de 1955, houve a aprovação da Lei $n^{\circ}$ 2.605, que tratava efetivamente do exercício profissional da enfermagem, definindo as categorias que poderiam exercer a enfermagem no país. Revogou as diversas categorias 
existentes dentro da enfermagem, tais como as de enfermeiros práticos, os práticos de enfermagem e os assistentes de enfermagem, entre outras denominações (Freitas, 2007).

Freitas (2007) destaca que antes da regulamentação da Lei $\mathrm{n}^{\circ}$ 2.605 de 17 de setembro de 1955, que ocorreu com o Decreto $\mathrm{n}^{\circ}$ 50.387, de 28 de março de 1961, houve a aprovação, no Congresso Nacional, de uma lei de grande relevância para a enfermagem, a Lei $\mathrm{n}^{\circ} 3.780$ de julho de 1960. Esta lei limitou as diversas denominações existentes à época na enfermagem. Apesar de não tratar especificamente da enfermagem, causou grande impacto na profissão, pois foi nesse momento que a enfermeira foi enquadrada como profissional técnico-científico de nível superior no serviço público federal. Esse fato contribuiu para que a enfermeira fosse, gradativamente, reconhecida e remunerada como profissional de nível universitário nos Estados e Município (Freitas, 2007).

Conforme apontado anteriormente, a Lei $\mathrm{n}^{\circ} 2.605 / 55$ foi regulamentada quase seis anos depois através do Decreto $\mathrm{n}^{\circ}$ 50.387/61. O que caracterizou este decreto foi a definição do exercício profissional, porém restrito à observação e ao cuidado de doentes, gestantes e acidentados; administração de medicamentos e tratamentos prescritos pelos médicos; educação sanitária e aplicação de medidas de prevenção de doenças (Freitas, 2007). A referida lei abordava também os deveres e proibições para o pessoal de enfermagem, exceto o técnico de enfermagem, que inexistia à época.

Os atuais dispositivos legais do exercício profissional da enfermagem são a Lei $n^{\circ}$ 7. 498, de 25 de junho de 1986, que dispõe sobre a regulamentação do exercício profissional em todo o território nacional e o Decreto $\mathrm{n}^{\circ} 94.406$ de 08 de junho de 1987 que regulamenta a lei do exercício profissional. 
Essa nova lei do exercício profissional não aponta o que seria enfermagem, porém estabelece as competências privativas da enfermeira. Foram também incluídas as atribuições dos demais profissionais da enfermagem, ou seja, do técnico e do auxiliar de enfermagem. Pela primeira vez as ações de enfermagem foram classificadas em atividades complexas e elementares.

Todas as profissões elaboram códigos com a intencionalidade de ofertar elementos para o pensar e o agir do profissional diante de si mesmo e do outro. As leis de cada profissão são elaboradas com a finalidade de proteger os profissionais, a categoria como um todo assim como a proteção das pessoas que dependem daquele profissional. Nesse sentido, o Conselho Federal de Enfermagem por intermédio da Resolução COFEN-311/2007 aprovou o Código de Ética dos Profissionais de Enfermagem vigente. Esse dispositivo legal reúne um conjunto de princípios, direitos, responsabilidades, deveres e proibições pertinentes à conduta ética dos profissionais de enfermagem (COFEN, 2009).

Em seu preâmbulo o Código de Ética dos Profissionais de Enfermagem diz que:

[...] leva em consideração a necessidade e o direito de assistência em enfermagem da população, os interesses do profissional e de sua organização. Está centrado na pessoa, família e coletividade e pressupõe que os trabalhadores de enfermagem estejam aliados aos usuários na luta por uma assistência sem riscos e danos e acessivel a toda população (COFEN, 2009).

Os principios fundamentais desse código afirmam que a enfermagem é uma profissão comprometida com a saúde e a qualidade de vida da pessoa, família e coletividade. Os profissionais de enfermagem devem atuar na promoção, prevenção, recuperação e reabilitação da saúde, com autonomia e em consonância com os preceitos éticos e legais (COFEN, 2009). 


\begin{abstract}
Enquanto membro integrante da equipe de saúde, o profissional de enfermagem participa das ações que visam a satisfazer as necessidades de saúde da população, garantindo a universalidade do acesso aos serviços de saúde, integralidade da assistência e a preservação da autonomia dos indivíduos (COFEN, 2009).
\end{abstract}

Em seu Art. $1^{\circ}$ o referido código diz que é direito do profissional de enfermagem "exercer a enfermagem com liberdade, autonomia e ser tratado segundo os pressupostos e princípios legais, éticos e dos direitos humanos" (COFEN, 2009).

Durante a execução das práticas de enfermagem, a responsabilidade assumida pela enfermeira pode ser descrita em duas modalidades primordiais, a saber: responsabilidade legal, que diz respeito ao cumprimento de cada um dos artigos contidos na Lei do Exercício Profissional da Enfermagem e a responsabilidade ética, compreendida incorretamente como acatar o Código de Ética de Enfermagem, uma vez que nenhum código de ética profissional abrange todos os dilemas éticos vivenciados durante as práticas (Oliveira, 2001).

Diante dos crescentes avanços da tecnologia na área de saúde, da complexidade de novos procedimentos e de novas situações na prestação do cuidado onde o campo das práticas de saúde passa a ser também as unidades básicas de saúde, as enfermeiras e demais membros da equipe de enfermagem têm-se deparado, freqüentemente, com questionamentos do agir profissional. Nesse contexto, é mister refletir sobre a dimensão das novas possibilidades apresentadas e considerar a relação entre o que é tecnicamente possivel e o que é eticamente lícito. 
O termo responsabilidade tem origem do latim. O dicionário Houaiss da língua portuguesa (2001), a define como "obrigação de responder pelas ações próprias ou dos outros". Enquanto termo jurídico a responsabilidade é definida como "dever jurídico resultante da violação de determinado direito, através da prática de um ato contrário ao ordenamento jurídico" (Houaiss, 2001).

Por vezes, a responsabilidade legal pode aparecer sobreposta de um caráter civil ou penal e, ainda, ético-profissional, abrangendo todos esses aspectos de forma cumulativa.

Sendo as responsabilidades civis e penais extensivas a todos os cidadãos, inclusive às enfermeiras, de forma individual ou coletiva, neste estudo tratamos de três modalidades de responsabilidade: civil, penal e ético-profissional.

A responsabilidade profissional pode transcender os aspectos ético-profissional e penal, podendo se tornar de natureza civil. Nessa esfera, tem-se por parâmetro a Lei $\mathrm{n}^{0} 10.406$ de 10 de janeiro de 2002, ou seja, o Código Civil vigente. Neste código, discute-se a responsabilidade profissional diante da ocorrência de prejuízo do usuário e a reparação ou ressarcimento do dano causado, que poderá ser de origem material ou moral, bem como o valor da indenização à vítima (Freitas, 2007).

O Art. 8 do Código Civil (2002) citado por Freitas (2007, p. 230), menciona que "aquele que, por ação ou omissão voluntária, negligência ou imprudência, violar o direito e causar dano a outrem, ainda que exclusivamente moral, comete ato ilícito".

Quando traçamos um paralelo com o Código de Ética dos Profissionais de Enfermagem observamos que seu artigo Art. 21 enfatiza que é responsabilidade e dever dos profissionais de 
enfermagem "Proteger a pessoa, família e coletividade contra danos decorrentes de imperícia, negligência ou imprudência por parte de qualquer membro da equipe de enfermagem" (COFEN, 2009).

No Brasil a legislação penal é regida pelo Decreto-lei $n^{\circ} 2.848$, de 07 de dezembro de 1948. Nesse dispositivo legal, a responsabilidade é entendida subjetivamente, ou seja, responde pelo delito o sujeito que praticou ou lesou direitos alheios, esclarecendo que quem delega uma função assume a responsabilidade pela ação que mandou fazer, juntamente com o executor desta ação.

Assim sendo, a enfermeira poderá ser convocada a responder legalmente pelos seus atos ou de outro profissional de enfermagem a ela subordinado, uma vez que delegar atividades de enfermagem não implica, necessariamente, em eximir-se da responsabilidade pelo fato de tê-las delegado. Pode-se tomar como exemplo o Art. 38 do Código de Ética dos Profissionais de Enfermagem que aponta ser dever do profissional de enfermagem "responsabilizar-se por falta cometida em suas atividades profissionais, independente de ter sido praticada individualmente ou em equipe."

Ainda quanto à responsabilidade penal, verifica-se que diversos artigos do Código de Ética dos Profissionais de Enfermagem encontram consonância com o Código Penal. Exemplificando: o Art. 28 proíbe o profissional de enfermagem de "provocar aborto ou cooperar em práticas destinadas a interromper a gestação" (COREN, 2009) e encontra paralelo nos artigos 125 e 128 do Código Penal que vedam a prática abortiva, exceto nos casos previstos em lei.

A responsabilidade ético-profissional se caracteriza pela infração ética que pode ser prevista no Código de Ética dos Profissionais de Enfermagem. Os artigos 12 e 21 do referido código fazem alusão à obrigação profissional da equipe de enfermagem de prestar 
assistência isenta de danos e de riscos oriundos de negligência, imprudência ou imperícia (COREN, 2009).

Para Freitas (2007, p. 239) "tal norma descreve a conduta esperada do profissional, a fim de evitar a ocorrência de quaisquer daquelas modalidades de culpa no exercício de atividades de enfermagem". O autor considera o Código de Ética dos Profissionais de Enfermagem genérico, cabendo às representações legais sua interpretação e aplicação em cada caso concreto.

A responsabilidade ética, segundo Iyer (1993) citada por Oliveira (2001), relaciona-se no campo da enfermagem, a duas correntes teóricas, a deontológica e a utilitarista. Conforme aponta Oliveira (2001), estudos indicam o predomínio de uma ética deontológica "baseada no cumprimento de deveres, daquilo que seria obrigatório na prática profissional das enfermeiras" apresentando uma visão reflexiva insatisfatória sobre o relacionamento com o outro e sobre suas práticas.

Em segundo plano, os mesmos estudos direcionam para a concepção utilitarista da responsabilidade ética, onde a bondade da ação reside exatamente no resultado das práticas, mais do que no respeito ao outro. Oliveira (2001, p.70) ressalta ainda que:

[...] as posturas profissionais decorrentes dessa concepção estão comumente associadas mais a uma forma de prazer individual do que algum dever de garantia e reconhecimento da dignidade do paciente.

Entendemos que o valor responsabilidade implica a utilização das noções de consciência e de racionalidade humana, ou seja, condição de reflexão frente às situações concretas. É um valor que não pode ser dissociado da noção de respeito e solidariedade frente à diferença do outro (Oliveira, 2001). 
Diante do exposto e norteando a reflexão sobre a enfermagem que tem como essência o cuidar, questiona-se: qual o valor que embasa a enfermagem, uma vez que é uma prática social dedicada a manter a vida, recuperar a saúde e enfrentar a doença? Como recuperar a dimensão original do cuidado enquanto essência humana? E qual é o elemento ético que fundamenta as práticas de enfermagem?

Os registros históricos apontam que durante a construção da prática do cuidado estão presentes dois valores a caridade e a solidariedade.

O termo caridade tem sua origem no latim e significa disposição favorável em relação a alguém em situação de inferioridade (fisica, moral, social etc.); benevolência, piedade (Houaiss, 2007).

Solidariedade, por sua vez, é a qualidade de ser solidário daquele que compartilha o sofrimento alheio e se propõe a mitigá-lo numa relação de responsabilidade ou interesse recíproco (CompteSponville, 1999).

Para Forcella et al (2005) solidariedade é a:

[...] virtude que explica a dependência mútua entre os seres humanos não como defeito, mas como condição de existência da sociedade. É o que leva os seres humanos a se auxiliarem mutuamente. São essenciais para a ação solidária quatro condições: a não indiferença; a aceitação da diferença; a doação, concessão e espera; a aprendizagem e a mudança.

Assim é possivel identificar as diferenças entre esses dois valores, uma vez que a caridade pressupõe benevolência e não existe a necessidade de reconhecer o outro como sujeito investido de poder; já a solidariedade é dependência mútua, implica na ação e no 
reconhecimento no poder de todos os sujeitos envolvidos em uma relação (Forcella et al 2005).

\title{
3.3 A visão filosófica do Cuidado
}

Estamos em um momento histórico onde a humanidade, desgastada com problemas como a violência, o descaso e as inquietudes buscam um sentido de viver e atuar, para uma nova percepção da realidade e por uma experiência do ser. Para Boff (2001, p. 25)

\begin{abstract}
A sociedade contemporânea, chamada de sociedade do conhecimento e da comunicação está criando, contraditoriamente, cada vez mais incomunicação e solidão entre as pessoas, [...]. O mundo virtual criou um novo habitat para o ser humano, caracterizado pelo encapsulamento sobre si mesmo e pela falta de toque, do tato e do contato humano. Essa anti-realidade afeta a vida humana naquilo que ela possui de mais fundamental: o cuidado e a com-paixão.
\end{abstract}

$\mathrm{Na}$ visão filosófica é pelo cuidado que se chega a uma sintonia com as coisas, a uma convivência. O cuidado possui uma dimensão ontológica, quer dizer, entra na construção do ser humano, é subjacente a tudo que o individuo planeja e realiza, além de constituir um modo-de-ser singular do sujeito, mediante o qual a pessoa sai de si e se centra no outro com desvelo e solicitude.

Segundo Boff (2005, p. 29) se

[...] não tomarmos o cuidado por base, não conseguiremos compreender o ser humano. Ele funda um novo ethos, no sentido originário da palavra ethos na filosofia grega: a forma como organizamos nossa casa, o mundo que habitamos com os seres humanos e com a natureza.

A origem da palavra cuidado em latim significa Cura. Em seu sentido mais antigo, cura se escrevia em latim coera e era utilizada em um contexto de relações humanas de amor e amizade. Cura 
queria expressar a atitude de cuidado, de desvelo, de preocupação e de inquietação pelo objeto ou pela pessoa amada. Existe ainda a derivação da palavra cuidado de cogitare-cogitatus, cujo significado é semelhante ao de cura, ou seja, cogitar e pensar no outro, colocar a atenção nele, denotar interesse por ele e revelar uma atitude de desvelo, até de preocupação pelo outro (Boff, 2005).

Boff (2005, p.29) considera que o cuidado por sua própria natureza

[...] inclui duas significações básicas, intimamente ligadas entre si. A primeira designa a atitude de desvelo, de solicitude e atenção para com o outro. A segunda nasce desta primeira: a preocupação e a inquietação pelo outro, porque nos sentimos envolvidos e afetivamente ligados ao outro.

Esses dois significados de cuidado ratificam a idéia de que ele é mais que um ato singular ou uma virtude ao lado de outras. É a forma como a pessoa humana se estrutura e se relaciona no mundo junto com demais sujeitos, ou seja, é a forma de ser-no-mundo. (Boff, 2005). Para Ayres (2004) e Boff (2005) há dois modos básicos de serno-mundo: o trabalho e o cuidado.

O modo de ser-no-mundo através do trabalho ocorre por intermédio da interação e intervenção do homem na natureza. A lógica desse modo de ser-no-mundo é a de situar-se sobre as coisas para dominá-las e colocá-las a serviço dos interesses pessoais e coletivos (Boff, 2005).

Para Boff (2005), o mundo que se organiza sob a égide do trabalho exclusivamente voltado para a dominação da natureza e para a exploração dos homens uns pelos outros, está trazendo uma ditadura do modo de ser do trabalho que masculinizou as relações, abriu espaço para o antropocentrismo, para o androcentrismo, patriarcalismo e machismo, difamando o cuidado como feminilização 
das práticas humanas, como empecilho à objetividade da compreensão e como obstáculo à eficácia.

A outra maneira de ser-no-mundo se realiza pelo cuidado. O cuidado não se opõe ao trabalho, mas lhe confere uma modalidade diferente. Pelo cuidado não vemos a natureza e tudo que nela existe como objetos. Nesse modo, as relações estabelecidas não são sujeitoobjeto, mas sujeito-sujeito (Boff, 2005).

O grande desafio para o ser humano é combinar trabalho com cuidado, como vimos ele não se opõem, mas se compõem para construírem juntos a integralidade da existência humana.

\subsection{Resgate histórico do Cuidado}

Em meados do século XVII, o hospital era considerado uma espécie de instrumento misto de exclusão, assistência e transformação espiritual, em que a função médica não tinha destaque. Os doentes eram assistidos por religiosos ou leigos que, além do espírito caritativo, buscavam a salvação da alma (Coelho, Fonseca, 2005).

A participação do profissional médico na cura dava-se por uma intervenção nos momentos de crise. A ele cabia atuar no processo saúde-doença de forma particularizada, ou seja, buscando a vitória da saúde e da natureza sobre a doença. Somente no século XVIII, quando o corpo sofredor passou a ser digno de atenção, os cuidados perdem seu caráter de agrado, de prazer e de satisfação, tomando como sua função o desenvolvimento e a manutenção da vida. Nesse período, os cuidados oriundos das descobertas empíricas passam a ser substituídas pelo cuidado técnico-científico (Coelho, Fonseca, 2005). 
Segundo Collière (1989) apud Coelho e Fonseca (2005), O objeto dos cuidados torna-se isolado, parcelizado, fissurado, separase das dimensões sociais e coletivas "[...] cuidar torna-se tratar a doença".

Neste sentido, Ayres (2004) descreve que desde os meados do século XIX, a racionalidade que orientou a ação de saúde em maior grau foi à lógica científica e suas estratégias reguladoras conduzindo as práticas de saúde à individualidade e ao desempenho do corpo.

Nessa perspectiva, Matumoto (2005) identifica que há predominância da lógica da produção de procedimento durante as práticas de saúde - consultas médicas, curativos, entre outro - que vem conformando os modelos assistenciais, sem assumir compromisso com os usuários e as suas necessidades. Para a autora, "os procedimentos passam a ser a finalidade última do trabalho e, assim, configura um modelo que é contraditório com a missão do próprio Sistema Único de Saúde: o cuidado" (Matumoto, 2005, p. 11).

Os avanços da medicina contemporânea e a sofisticação tecnológica apresentam efeitos positivos e negativos nas práticas de saúde. De um lado, reconhece-se como importante o avanço, a rapidez e ampliação dos métodos diagnósticos, a intervenção terapêtica cada vez mais precoce, a melhora do prognóstico e da qualidade de vida. Como contrapartida, a segmentação do indivíduo em órgãos ou funções, o intervencionismo inadequado, a desatenção com os aspectos psicossociais do processo de adoecimento e a iatrogenia são alguns dos limites desses avanços (Ayres, 2004).

Atualmente existe uma tentativa de resgate do cuidado. Neste sentido, Craco (2006, p.127) argumenta que o cuidado precisa ser: 
cientifico ou a tecnologia dura, envolvendo questões como o não técnico, saber popular, idéias e horizontes de vida, bem como o desenvolvimento de tecnologias leves que caminha ao encontro do acolhimento, ao vinculo, à autonomia, ao reconhecimento das diferenças e das contradições presentes no ato de cuidar.

Para Ayres (2004), o momento assistencial deve fugir de uma interação tão obcecada pelo “objeto de intervenção”, possibilitando perceber e aproveitar as trocas mais amplas que esse momento propicia. O autor aponta que a ação assistencial se revestirá efetivamente do caráter de cuidado quando o profissional da saúde não prescindir:

[...] da ausculta do que o outro (o paciente ou os grupos populacionais assistidos) deseja como modo de vida e como, para atingir esse fim, pode lançar mão do que está disponível (saberes técnicos inclusive, mas não só, pois há também os saberes populares, as convicções e valores pessoais, a religião etc.), então de fato já não há mais objetos apenas, mas sujeitos e seus objetos (Ayres, 2004, p.86).

Corroborando com o exposto por Ayres, Matumoto (2005, p.12) afirma que:

A ação de saúde centrada na lógica da produção do cuidado traduz-se no trabalho orientado aos problemas, às necessidades e à qualidade de vida do usuário. São ações que, além de produzir os procedimentos inerentes ao caso, como uma sutura, uma consulta ou um curativo, por exemplo, centram atenção nas relações humanas, na produção de vínculo, no acolhimento, na autonomia do usuário no cuidado de si. Utiliza principalmente as tecnologias leves que produzem bens-relação.

Assim, o ato de saúde de um trabalhador junto a um usuário produz um encontro entre duas "pessoas" que atuam uma sobre a outra e no qual opera um jogo de expectativas e produções. Para Merhy (1998) é esse momento que possibilita a criação de

[...] instantes de intersubjetividade, tais como: momentos de falas, escutas e interpretações, no qual há a produção de uma acolhida ou não das intenções que estas pessoas colocam neste encontro; momentos de cumplicidades, nos 
quais há a produção de uma responsabilização em torno do problema que vai ser enfrentado; momentos de confiabilidade e esperança, nos quais se produzem relações de vínculo e aceitação.

Nesse sentido, Pires (2005, p. 1031) sustenta que:

Cuidar é mais que um ato mecanizado, rotinizado e alienado de sentido, faz parte da realidade criativa dos seres, compondo-lhe a estrutura de ser e vir a ser-no-mundo, sendo atitude humana inscrita na esfera vital, subjetiva e cultural das relações sociais.

Para a autora o "aprisionamento do ato de cuidar em normas, rotinas e técnicas desvirtuam o cuidado de sua existência criadora e reveladora" (Pires, 2005, p.1031). Produz-se assim a institucionalização do cuidado. Esse cuidado institucionalizado tende a priorizar a proteção do usuário em detrimento de sua autonomia.

Waldow (2008b) considera o cuidado como um fenômeno existencial, uma vez que, faz parte do ser, the confere a condição de humanidade; racional por se dar em relação ao outro ser, se mostrar na co-existência como outros sujeitos e contextual porque assume variações, intensidades, diferenças na maneiras e nas expressões de cuidar conforme o meio em que ocorre.

Portanto, o cuidado pode ser entendido como um processo que ocorre entre dois ou mais indivíduos e que faculta crescimento e a mudança naqueles nele envolvidos.

\subsection{Enfermagem - a essência no cuidar}

Historicamente a enfermagem se evidencia como um fazer centrado no cuidar. Após o movimento reformista de Florence Nightingale, o cuidado assume uma nova face, passa-se a dar importância à higiene, ao ambiente e ocorre a preocupação em realizar essas ações com conhecimento (Almeida, 1997). 
Porém, essas mudanças não possibilitaram alterar o comportamento e a atitude de algumas enfermeiras, que continuam com a dualidade nas ações, obediência, docilidade, com prevalência do autoritarismo.

O advento da revolução industrial e da era da ciência traz para a enfermagem e demais profissões de saúde a idolatria pela técnica. São valorizadas as atividades de cunho terapêutico enfocando a doença; a pessoa passa a ser secundarizada e as ações elementares menosprezadas e delegadas. Nesse periodo, a enfermagem na busca de obter reconhecimento e caracterizar-se enquanto ciência se mira no modelo biomédico de assistência, ou seja, na lógica da produção de procedimento (Waldow, 2008c).

$\mathrm{Na}$ década de sessenta dá-se o inicio do desenvolvimento das teorias de enfermagem nos Estados Unidos da América e a propagação destas aos demais países. As teorias desenvolvidas por enfermeiras norte-americanas têm como ênfase os aspectos biomédicos, resultando no cuidado tecnicista, reforçando a forma de cuidar da época.

Waldow (2008b) observou que as pesquisas na fase atual de enfermagem buscam discutir e questionar seu conhecimento, apontando que existe a tendência de se adotar em suas práticas abordagens plurais. A autora aponta que:

\footnotetext{
Uma tendência observada e já evidenciada nas abordagens das pesquisas mais recentes é a de um enfoque mais humanista na enfermagem. Observa-se uma tendência de privilegiar uma pluralidade de abordagens, o que equivale permitir que se discutam diferentes maneiras de pensar, fazer e ensinar enfermagem (Waldow, 2008b, p. 90).
}

Esse enfoque mais humanista na enfermagem possibilita reflexões sobre a maneira como ocorrem os cuidados prestados ao sujeito. 
Opostamente ao que alguns profissionais de enfermagem argumentam, o resgate do cuidado não é uma rejeição aos aspectos técnicos, tampouco ao aspecto científico. Conforme Waldow (2008b, p. 90) o que se pretende com esse resgate "é enfatizar a característica de processo interativo, assim como do componente emocional, da intuição que caracterizam a sua dimensão artística, além da dimensão moral que contém.”

$\mathrm{Na}$ enfermagem, o cuidado não se resume a uma emoção, preocupação, atitude ou um desejo de realizar o bem. Cuidar é considerado o ato moral cuja finalidade é a proteção, o desenvolvimento e a preservação da dignidade humana. O cuidado envolve valores, um desejo e um compromisso para cuidar além de conhecimento técnico-científico (Waldow, 2008c).

Conforme abordado anteriormente, a enfermagem durante a construção da prática do cuidado apresenta dois valores, a caridade e a solidariedade. Para tanto, é mister que os profissionais de enfermagem enxerguem e executem os cuidados na perspectiva da solidariedade, ou seja, da prática social, histórica e socialmente construída em torno de ações de seu campo de atuação, que têm por finalidade transformar o outro - e o próprio profissional - em sujeitos dotados de responsabilidade, portanto, de poder para o exercício de cidadão de direitos e deveres.

Waldow (2008c, p.87) assevera que na enfermagem, o cuidado

[...] compreende os comportamentos e atitudes demonstradas nas ações que lhe são pertinentes e asseguradas por lei e desenvolvidas com competência no sentido de favorecer as potencialidades das pessoas para manter ou melhorar a condição humana no processo de viver e morrer.

Assim, a característica básica das práticas de enfermagem está estabelecida na sua potencialidade de desenvolver, de forma 
contínua, o cuidado como intervenção sobre problemas de saúde da população, de grupos e indivíduos isoladamente.

Para Rodrigues (1998, p.48):

\begin{abstract}
As enfermeiras têm em comum o compromisso de uma prática que, em qualquer lugar do país, nos coloca na posição de cidadão na frente de outro cidadão, aos quais deve ser assegurado o direito de atenção à saúde. Isso pressupõe o esforço dos profissionais de saúde para a construção de prática que devem ter como respaldo a visão do processo saúde-doença em sua dimensão coletiva para que a prática assistencial se consolide em novos paradigmas. Paradigmas esses que colocam o ser humano como ser integral.
\end{abstract}

Nesse sentido, o cuidado poderá ser transformador se: ativar os saberes dos indivíduos e dos grupos populacionais, geralmente desqualificados, descontínuos e não hegemônicos; enfrentar continuadamente os problemas de saúde, tidos como produto da organização da sociedade referentes a perfis epidemiológicos próprios, de acordo com a inserção social dos indivíduos e grupos; tiver como parceiros todos os que vivem na mesma sociedade; considerar a enfermagem um campo de conhecimentos técnicos e sociais; o outro, a quem ele se dirige, for protagonista deste mesmo cuidado (Rodrigues, 1998).

\title{
3.6 A Atenção Básica e a estratégia Saúde da Família
}

Percebendo a expansão do Programa Saúde da Família (PSF) que se consolidou como estratégia prioritária para a reorganização da Atenção Básica no Brasil e considerando a necessidade de revisão e adequação as normas nacionais ao atual momento do desenvolvimento da atenção básica de saúde, o governo brasileiro emitiu a Portaria $N^{\circ}$ 648, de 28 de Março de 2006, que institui a Política Nacional de Atenção Básica (PNAB). 
Entre as principais mudanças trazidas pela PNAB, destaca-se o conjunto de princípios gerais que devem conduzir a Atenção Básica, assim como a mudança da nomenclatura da Saúde da Família de "programa” para "estratégia", com vistas a estabelecer a Saúde da Família como a forma principal por meio da qual se pretende chegar à reorientação do modelo de atenção (Brasil, 2006).

Quanto ao acesso, deve se constituir no contato preferencial dos usuários com os sistemas de saúde, orientado pelos princípios da universalidade, da acessibilidade e da coordenação do cuidado, do vínculo e continuidade, da integralidade, da responsabilização, da humanização, da equidade e da participação social. No campo das práticas de saúde, é importante e necessário que os sujeitos sejam considerados em sua singularidade, na complexidade, na integralidade e na inserção sócio-cultural, buscando a promoção de sua saúde, a prevenção e tratamento de doenças e a redução de danos ou de sofrimentos que possam comprometer suas possibilidades de viver de modo saudável (Brasil, 2006).

A estruturação da estratégia da Saúde da Família na lógica da atenção básica à saúde gera novas práticas de saúde e estabelece a indissociabilidade entre os trabalhos clínicos e a promoção da saúde. Segundo Ermel (2006), para o alcance dessa proposta é necessário:

[...] desenvolver processos de trabalho que estabeleçam uma nova relação entre os profissionais de saúde e a comunidade, estes processos de trabalho devem se traduzir, especialmente, em termos de desenvolvimento de ações humanizadas, tecnicamente competentes, intersetorialmente articuladas, e socialmente apropriadas (Ermel 2005,p. 534).

Almeida (1997) relata que o início da atuação da enfermeira no Programa Saúde da Família ocorreu na década de 70 do século passado, cabendo a essa profissional as atividades predominantemente gerencias tais como: supervisão, treinamento, controle e coordenação do pessoal de enfermagem, além de atuar 
também, na vigilância epidemiológica, nas reuniões com grupos da comunidade, na visita domiciliária e nas atividades educativas.

Em meados da década de 80, devido à centralidade do pronto atendimento como modalidade de organização da atenção básica, o cuidado prestado pela enfermeira de saúde pública passou a ter seu cerne no auxílio ao pronto atendimento médico, "pautado num recorte clínico e individual, tornando-se rara a realização de ações de caráter coletivo" (Ermel, 2006, p. 534).

Somente com a implementação do Sistema Único de Saúde, os serviços públicos de saúde resgataram a necessidade de mudança no modelo assistencial até então adotado. Contudo, apenas em meados de 1990, o programa de Saúde da Família recolocou em discussão a necessidade de mudança no modelo assistencial na perspectiva do processo saúde-doença em sua dimensão coletiva e conseqüentemente buscando construir práticas de saúde fundamentadas em novos paradigmas.

$\mathrm{Na}$ estratégia da Saúde da Família, as práticas de saúde desenvolvidas pelas enfermeiras se incluem buscando a integração das ações com os demais membros da equipe de saúde. Assim, segundo Ermel (2006, p. 534):

[...] para a compreensão da especificidade do trabalho da enfermeira no PSF é imprescindivel que se analise a sua inserção no trabalho da equipe, o modo como se dá sua relação com o processo de trabalho e o modo como a enfermeira realiza o cuidado especifico de enfermagem.

Nesse sentido, a enfermagem enquanto prática social, ou seja, como trabalho que se articula a outros trabalhos em contextos históricos e sociais específicos indo além de uma profissão com sua competência técnico-científica, busca sempre responder às exigências 
sociais e de saúde de uma determinada época e de um determinado espaço social.

Segundo Silva (2006), os encontros entre as enfermeiras e os usuários nas unidades básicas de saúde são mais freqüentes e em situações de menos urgência, diferentes dos ocorridos na atenção terciária que pede prontas soluções.

Essa divergência das práticas de saúde nos serviços tem importância na medida em que os problemas de ordem ética emergem do contexto no qual estão inseridos. Assim, as situações vivenciadas, por exemplo, nos prontos socorros fazem com que os problemas éticos sejam freqüentemente mais evidentes, enquanto nas unidades básicas de saúde apresentam-se tipicamente de maneira mais sutil, passando, muitas vezes, despercebidos (Zoboli, 2003). 


\section{Caminho metodológico}

\subsection{Tipo de estudo}

Trata-se de uma pesquisa social, conceituada por Minayo (2006, p.47) como "todas as investigações que tratam o fenômeno saúde-doença, de sua representação pelos vários atores que atuam no campo: as instituições politicas e de serviço e os profissionais e usuários".

Por esta razão, a pesquisa adotou o enfoque qualitativo indicado por Minayo (2006) para viabilizar o estudo da história, das relações, das representações, das crenças, das opiniões, produtos das interpretações que os humanos fazem a respeito de como vivem, constroem seus artefatos e a si mesmos, sentem e pensam.

A pesquisa qualitativa trabalha "com o universo de significados, motivos, aspirações, crenças, valores e atitudes, o que corresponde a um espaço mais profundo das relações, dos processos e dos fenômenos" Minayo (2006, p.21).

O estudo qualitativo e exploratório teve como marco teóricometodológico o materialismo histórico e dialético. É histórico porque entende que esses fenômenos estão situados em um tempo e uma realidade historicamente construídos e dialético porque considera que essa realidade está em constante transformação pela ação do ser humano (Egry, 1996).

Tomamos a dialética como um pressuposto importante no entendimento da teoria e dos dados empíricos obtidos no cenário em que o estudo foi desenvolvido. 
Para Baraldi (2005, p. 44):

O movimento dialético permite conhecer e reconhecer as
realidades, possibilidades e limites inerentes à visão de
mundo aqui desenhada, num processo de construção e
desconstrução que se transforma e dinamiza, daí, portanto,
sua historicidade. Estes horizontes constituem a complexa
engrenagem de situações que vão desenvolvendo o traçado
da história dos individuos e da sociedade, interagindo
diretamente na práxis profissional. O pensar dialético pede
para reconsiderar o homem no interior de determinada
sociedade, contextualizando-a num específico momento
histórico, sofrendo interferência dos plexos em que estão
conectados num constante processo de organizar,
desorganizar e transformar.

Minayo (2006, p. 167) aponta que "a dialética busca nos fatos concretos, na linguagem, nos símbolos e na cultura, os núcleos obscuros e contraditórios para realizar uma crítica sobre eles".

A concepção materialista dialética ajuda a compreender a prática social, entendendo-a em constante transformação, onde os atores sociais e a estrutura social são capazes de modificá-la.

Como neste estudo pretendeu-se observar as interações estabelecidas entre as enfermeiras e os usuários durante a prestação do cuidado, no ambiente de uma unidade básica de saúde, inferimos que a pesquisa qualitativa seria a mais adequada para abarcar a complexidade do fenômeno a ser estudado, uma vez que permite uma observação mais ampla da situação, além da participação mais direta da pesquisadora no processo.

O projeto de pesquisa foi submetido e aprovado pelo Comitê de Ética e Pesquisa da Escola de Enfermagem da Universidade de São Paulo, conforme o Processo no 730/2008/CEP-EEUSP (Anexo 2). 


\subsection{Local de coleta e fonte de dados empiricos}

A coleta de dados foi realizada no Distrito de Capão Redondo, da Coordenadoria de Saúde Sul, Supervisão de Área de Saúde de Campo Limpo vinculada à Secretaria Municipal de Saúde, nas Unidades Básicas de Saúde do Jardim Comercial, Jardim Maracá e Parque do Engenho II, da Prefeitura de São Paulo. Os sujeitos da pesquisa foram 15 enfermeiros que compunham as equipes de saúde da família destas unidades.

Os dados foram coletados através de um formulário de caracterização sócio-econômica dos participantes (Apêndice 1) e de entrevistas realizadas com o objetivo de coletar situações, mediante a solicitação de um relato circunstanciado, em detalhes, de um fato verídico, relacionado às práticas de enfermagem realizadas nos locais de trabalho, conforme roteiro pré-estabelecido (Apêndice 2).

A participação dos sujeitos se deu de maneira voluntária mediante convite. As entrevistas foram gravadas, transcritas sendo mantidas, ao máximo, as falas de forma integral.

As enfermeiras participantes do estudo receberam o Termo de Consentimento Livre e Esclarecido (Apêndice 3) onde foram apresentados o tema e os objetivos da pesquisa, assegurando-lhes que as informações que subsidiaram a obtenção dos dados relacionados à dimensão do saber-ser ético-profissional seriam tratadas no anonimato, em consonância com disposto pela Resolução $n^{\circ}$ 196/96 do Conselho Nacional de Saúde que estabelece as diretrizes e normas regulamentadoras em pesquisas envolvendo seres humanos.

Minayo (2006) considera que entre as técnicas existentes de pesquisa qualitativa a entrevista seja a mais utilizada no campo de 
trabalho. Para a autora a entrevista não significa um conversa neutra, uma vez que introduz como elemento de coleta de dados os fatos relatados pelos atores, enquanto sujeitos-objeto da pesquisa que vivenciam uma determinada realidade que está sendo investigada.

Por intermédio da entrevista obtemos informações categorizadas em dois grupos, os objetivos e os subjetivos. As pertencentes ao primeiro grupo podem também ser conseguidas por intermédio de diferentes fontes, tais como censos, estatísticas e outras formas de registro. Em contrapartida, o segundo grupo se relaciona aos valores, às atitudes e às opiniões dos sujeitos entrevistado. Minayo (2006, p. 262) considera que a entrevista possibilita o alcance de:

[...] informações que tratam da reflexão do próprio sujeito sobre a realidade que vivencia [...]. Constituem uma representação da realidade: idéias, crenças, maneira de pensar; opiniões, sentimentos, maneiras de atuar, condutas; projeções para o futuro; razões conscientes e inconscientes de determinadas atitudes e comportamentos.

Nesse sentido, aplicamos a técnica de entrevista semiestruturada, que combina perguntas fechadas e abertas, onde o entrevistado tem a possibilidade de discorrer sobre o tema abordado sem se prender a questões formuladas (Minayo, 2006).

A opção por essa técnica de pesquisa, entrevista semiestruturada, deveu-se à vantagem desse instrumento na coleta de informações, pois a fala é reveladora de condições estruturais, de sistemas de valores normas e símbolos, possibilitando a transmissão, através de porta-voz, das representações de grupos específicos, em condições históricas, sócio-econômicas e culturais específicas (Minayo, 2006) 


\subsection{Cenário do Estudo}

A Lei Municipal de $\mathrm{N}^{\circ}$ 13.399, de $1^{\circ}$ de agosto de 2002 (São Paulo, 2002) demarca o Município de São Paulo em trinta e uma subprefeituras, entre elas a de Campo Limpo, composta pelos Distritos de Campo Limpo, Capão Redondo e Vila Andrade.

O Sistema de Saúde no Município de São Paulo, conforme determina o Decreto Municipal No. 45.037, de 20 de julho de 2004 (São Paulo, 2004), está organizado em cinco Coordenadorias de Saúde vinculadas às subprefeituras e encarregadas de desempenhar as funções de gestão do Sistema Único de Saúde (SUS), nas respectivas áreas de atuação, mediante delegação da Secretaria Municipal de Saúde.

O estudo foi desenvolvido na Supervisão de Área de Saúde de Campo Limpo da Coordenadoria de Saúde Sul, especificamente no Distrito de Capão Redondo que reúne os distritos administrativos de Campo Limpo, Capão Redondo e Vila Andrade.

A população residente na Coordenadoria de Saúde Sul totaliza 2.590.279 habitantes sendo que na Supervisão de Área do Campo Limpo residem $22,67 \%$, assim distribuídos entre os distritos: Campo Limpo 215.451 habitantes; Capão Redondo 274.047 habitantes e Vila Andrade 97.395 habitantes (CEInfo, 2008).

A figura 1 apresenta a demarcação geográfica da Supervisão de Área de Saúde de Campo Limpo e seus respectivos distritos administrativos. 
Figura 1 - Supervisão de Área de Saúde de Campo Limpo e respectivos distritos administrativos.

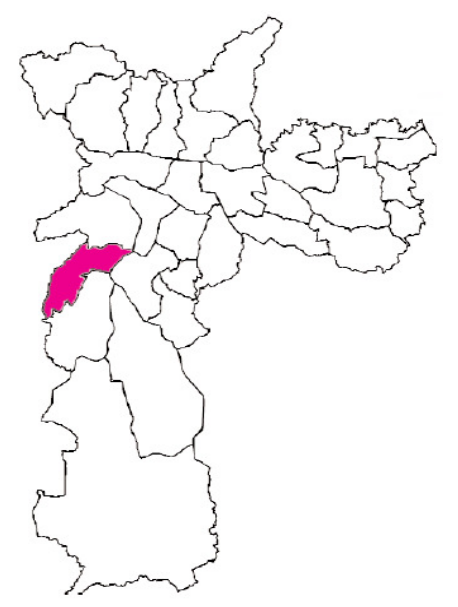

Distritos Administrativos

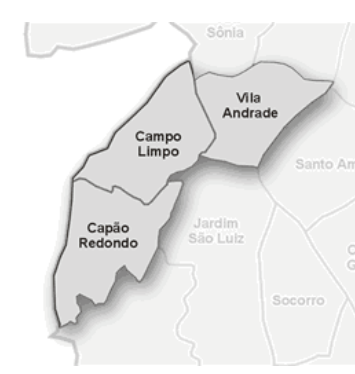

Fonte: Prefeitura do Município de São Paulo (PMSP). Sumário de dados do municipio de São Paulo, 2004. 2 Disponivel em http://portal.prefeitura.sp.gov.br/secretarias/governo/sumario_dados/0002. Acessado em 03/03/2009.

A pirâmide populacional apresentada na Figura 2 mostra uma concentração de jovens entre 15 a 29 anos, porém, verifica-se a ocorrência do estreitamento acentuado nas idades de 30 a 59 anos. Esse afunilamento pode representar condições de vida desfavoráveis. Um dado que corrobora com a informação é o total de 502 óbitos, ocorridos no ano de 2003, na faixa etária de 40 a 59 anos, correspondendo a $24,17 \%$ do total da Subprefeitura de Campo Limpo (PMSP, 2004). Demonstra ainda as caracteristicas de subdesenvolvimento da região do cenário do estudo, com maior concentração populacional nas faixas mais jovem e menor na faixa etária mais avançada. Outro dado que aponta o subdesenvolvimento regional é o aumento do número de mulheres na medida em que as idades avançam, chegando às faixas de maior idade com o dobro de mulheres em relação ao quantitativo de homens. 
Figura 2 - Pirâmide populacional da Subprefeitura de Campo Limpo.

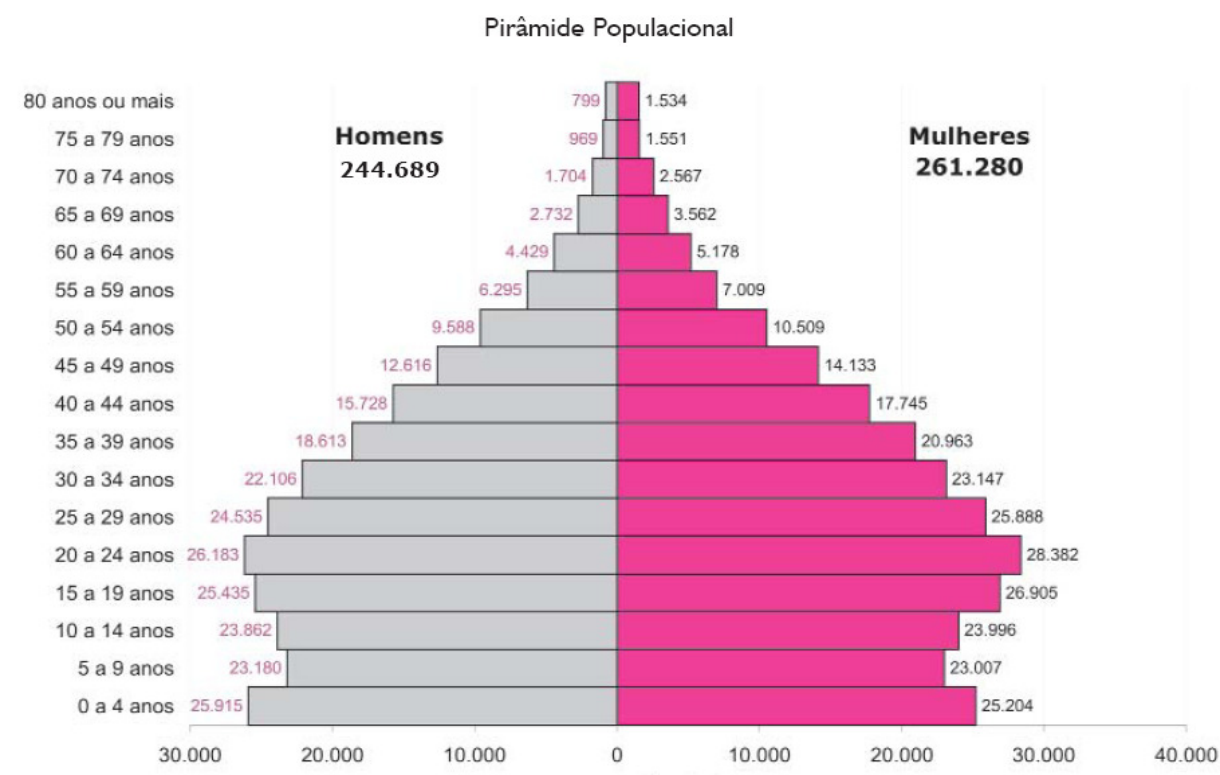

Fonte: Prefeitura do Município de São Paulo (PMSP). Sumário de dados do município de São Paulo, 2004. Disponivel em http://portal.prefeitura.sp.gov.br/secretarias/governo/sumario_dados/000 2. Acessado em 03/03/2009.

A área total da subprefeitura de Campo Limpo corresponde a $36,7 \mathrm{~km}^{2}$, o que implica uma densidade demográfica de aproximadamente 15.992 habitantes / km². A Fundação Seade (2007) traz como destaques os seguintes indicadores sociais: $24,26 \%$ residem em favelas da região; a taxa de analfabetismo é cerca de $7 \%$, maior que o do Município de São Paulo (4,88\%); entre os chefes de família, a escolaridade de maior incidência é do Ensino Fundamental Completo (40,10\%); a média de anos de estudo dos chefes das famílias é de 6,54 anos, menor que do Municipio (7,67 anos); o rendimento do chefe da família em 55,96\% é de cinco salários mínimos (PMSP, 2004). A taxa de mortalidade infantil, indicador privilegiado para apontar as condições de vida da população, foi de 13,7 por mil crianças nascidas vivas durante o ano de 2007, enquanto que o município de São Paulo apresentou uma taxa de 
12,6. Quanto ao quantitativo de mulheres gestantes adolescentes (até 19 anos), no primeiro semestre de 2008, houve 682 correspondendo a $14,21 \%$ das gestantes, valor elevado quando comparado ao município de São Paulo (13,80\%). (SINASC, 2008). Conforme dados da Coordenação de Epidemiologia e Informação (CEInfo, 2008), as três principais causa de morte na região , em ordem decrescente, foram doenças aparelho circulatório; neoplasias e homicídios.

Quanto aos equipamentos de saúde, a região conta com 296 leitos hospitalares, o que corresponde a 0,52 leitos por mil habitantes, muito diferente da taxa no Município de São Paulo que é de 3,16 leitos por mil habitantes. Os demais equipamentos vinculados à Supervisão Técnica de Saúde do Campo Limpo estão expressos no Quadro 01.

Quadro 1 - Equipamentos de Saúde da Subprefeitura de Campo Limpo

\begin{tabular}{|l|c|}
\hline \multicolumn{1}{|c|}{ Equipamentos Municipais } & \multicolumn{1}{|c|}{$\begin{array}{c}\text { Total de } \\
\text { equipamentos }\end{array}$} \\
\hline Unidade Básica de Saúde (UBS) & 21 \\
\hline Assistência Médica Ambulatorial (AMA) & 04 \\
\hline $\begin{array}{l}\text { Centro Testagem Acompanhamento } \\
\text { DST/AIDS }\end{array}$ & 01 \\
\hline Centro de Atenção Psicossocial Adulto & 01 \\
\hline $\begin{array}{l}\text { Centro de Convivência e Cooperativa } \\
\text { (CECCO) }\end{array}$ & 02 \\
\hline $\begin{array}{l}\text { Clínica de Especialidades Odontológicas } \\
\text { (CEO) }\end{array}$ & 02 \\
\hline Pronto Atendimento (PA) & 01 \\
\hline $\begin{array}{l}\text { Serviço de Atendimento Especializado } \\
\text { DST/AIDS }\end{array}$ & 01 \\
\hline
\end{tabular}

Fonte: Secretaria Municipal da Saúde - Coordenadoria de Epidemiologia e Informação / CEInfo, 2008 


\subsubsection{Distrito de Capão Redondo}

No estudo foi considerado o distrito administrativo de Capão Redondo, cuja extensa geográfica corresponde a $13,6 \mathrm{~km}^{2}$. Possui 274.047 habitantes que resulta na densidade demográfica de 20.150 mil habitantes por $\mathrm{km}^{2}$ (DATASUS, 2009).

Trata-se de um distrito periférico, considerado dormitório e que já foi apontado como uma das áreas mais violentas de São Paulo, situação que vem se revertendo nas últimas pesquisas apontando redução das taxas de crimes nesta região.

Quanto à idade, a distribuição da população assim se encontra distribuida: 24.977 menores de 5 anos, 48.343 entre 5 e 14 anos, 133.394 entre 15 e 44 anos, 54.572 entre 45 e 64 anos e 12.761 com 65 anos e mais (DATASUS, 2009).

Em relação à renda familiar, 47,73\% das pessoas responsáveis pelos domicílios recebiam entre 1 e 3 salários mínimos, 31,64\% viviam com renda entre meio a um e meio salários mínimos e somente $1,74 \%$ informaram renda superior a 10 salários mínimos (Fundação SEADE, 2007).

Aproximadamente $31 \%$ da população residem em favelas e a taxa de mortalidade por causas externas é de 44,74 por mil habitantes (SINASC, 2008) A organização da rede municipal de saúde, neste distrito, é formada por um pronto atendimento na UBS Jardim Macedônia, três unidades de Assistência Médica Ambulatorial, um Centro de Atenção Psicossocial Adulto, um Centro de Convivência e Cooperativa Santo Dias. Na totalidade das onze unidades básicas de saúde (UBS) encontra-se a estratégia Saúde da Família. Segundo Nakamura (2009), as 11 UBS contam com 75 equipes de saúde da família. O número de profissionais está assim 
distribuído: 75 médicos; 75 enfermeiras; 150 auxiliares de enfermagem; 445 agentes comunitários de saúde e 78 assistentes técnicos administrativos.

Nas UBSs encontravam-se cadastradas 78.413 familias totalizando 283.135 pessoas, sendo 130.498 do sexo masculino e 152.637 do sexo feminino. O percentual de cobertura do Programa de saúde da Família no Capão Redondo é de 94,7\%. (Nakamura, 2009).

A coleta dos dados desta pesquisa foi realizada nas seguintes unidades: UBS Jardim Comercial; UBS Jardim Maracá e UBS Parque do Engenho.

A Figura 3 mostra a distribuição das unidades de saúde da família do distrito de Capão Redondo.

Figura 3 - Unidades Básicas de Saúde localizadas no Distrito de Capão Redondo.

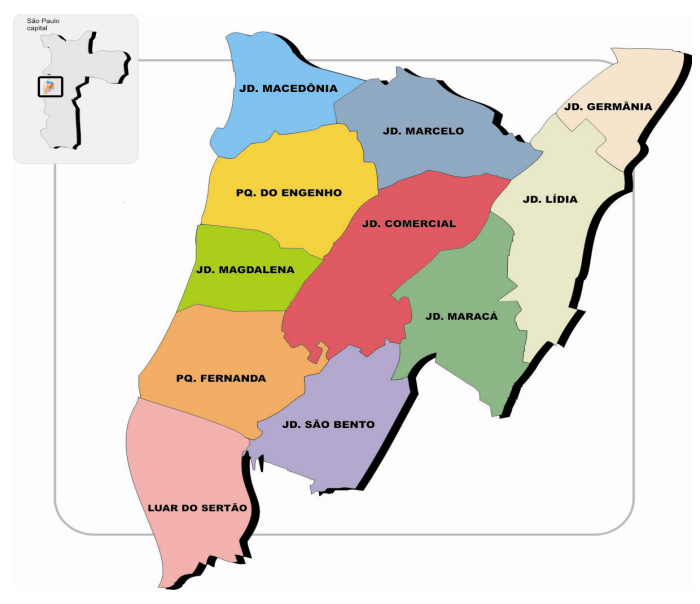




\title{
4.4 Análise dos dados
}

Partindo da análise qualitativa do material obtido das entrevistas, foi utilizado o método de análise de conteúdo das situações relatadas pelos participantes do estudo, com a finalidade de compreender o conjunto de significados, ações, valores, atitudes e sentimentos relacionados às práticas de saúde de acordo com o objeto de estudo.

Para Bardin, análise de conteúdo pode ser definida como:

\begin{abstract}
Um conjunto de técnicas de análise de comunicação visando obter, por procedimentos sistemáticos e objetivos de descrição do conteúdo das mensagens, indicadores (quantitativos ou não) que permitem a inferência de conhecimentos relativos às condições de produção/recepção destas mensagens. (Bardin, 1977, p.42)
\end{abstract}

Após as transcrições das fitas foram realizadas leituras cuidadosas de todo o conteúdo com a finalidade de torná-los familiares ao pesquisador.

Posteriormente, as entrevistas foram lidas separadamente, elaboradas as situações e extraídos trechos significativos que expressassem os valores, atitudes e sentimentos dos profissionais durante o cotidiano de suas práticas de enfermagem das enfermeiras da unidade básica de saúde.

A apresentação dos depoimentos seguiu a proposta metodológica de Bourdieu (2003), ou seja, a construção de situações sem fragmentá-las, ressaltando os termos essenciais, sem alteração substantiva da estrutura do diálogo e tentando, sempre que possivel, conservar os detalhes. Atenção especial foi dada aos dados que são frutos da linguagem não verbal como a linguagem corporal, gestual, postural, silêncios, subentendidos e lapsos. 
Posteriormente, os conteúdos foram analisados segundo os marcadores existentes para a dimensão do saber-ser éticoprofissional do auxiliares de enfermagem (anexo 1), com o objetivo de identificar a aplicabilidade destes marcadores nas práticas das enfermeiras das unidades básicas de saúde.

Os marcadores da dimensão do saber-ser ético-profissional dos auxiliares de enfermagem é o resultado da pesquisa "As práticas de enfermagem e as competências do saber-ser" (Fonseca et al, 2006). Essa pesquisa teve como objetivos, entre outros, conhecer situações do cotidiano da prática profissional dos auxiliares de enfermagem em que possam ser detectadas competências relacionadas ao saber-ser; analisar estas práticas à luz das competências esperadas dos auxiliares de enfermagem, bem como dos valores e virtudes relacionadas à convivência humana que as embasam.

A investigação, para a realização da pesquisa, sobre as práticas profissionais dos auxiliares de enfermagem, tanto nas unidades extra-hospitalares e intra-hospitalares, revelou que das situações analisadas emergiram valores, significando que, do ponto de vista ético-profissional, a prática destes profissionais de enfermagem se assentava primordialmente neles.

Os valores identificados foram compreensão, respeito, solidariedade, responsabilidade, generosidade, bondade, tolerância, honestidade, lealdade, união, humildade, cooperação, compaixão, justiça, autonomia, iniciativa e empatia.

A etapa final do estudo proposto validou, por intermédio de oficinas de trabalho com enfermeiras assistenciais e especialistas na área de ética e ética profissional, os oito marcadores do saber-ser ético-profissional dos auxiliares de enfermagem, a saber: 
- Compreender o âmbito das ações da enfermagem na produção de serviço de saúde.

- Mobilizar saberes para avaliar contextos e tomar decisões.

- Interagir com o usuário e seus familiares, demonstrando atenção às várias formas de manifestação de suas necessidades e demandas.

- Perceber, compreender e respeitar-se como cidadão e como trabalhador de saúde.

- Demonstrar responsabilidade para com usuários e equipe nas situações de trabalho.

- Interagir com equipe de trabalho de acordo com os valores que regem o trabalho da enfermagem.

- Respeitar os direitos dos usuários como cidadão.

- Compreender e posicionar-se frente às condições de trabalho existentes nas instituições.

Os marcadores acima descritos foram o ponto de partida para a discussão a que o presente estudo se propõe, ou seja, investigar como se expressa a dimensão do saber-ser ético-profissional das enfermeiras nas práticas profissionais em uma unidade básica de saúde. 


\section{Resultados e Discussão}

Do total de 15 entrevistas feitas, foram selecionadas 16 situações para análise. Em duas entrevistas foram obtidas duas situações cada, o que totalizou 17 situações, porém uma foi descartada por não se enquadrar no critério estabelecido que foi possibilitar a identificação de valores, atitudes e sentimentos, bem como detectar a presença dos marcadores do saber-ser éticoprofissional nos discursos das enfermeiras. Vale dizer que a análise detectou a aderência ou não ao marcador considerado, bem como a presença de valores e contra-valores, expressando assim o saber-ser ético-profissional tanto na sua face vinculada ao Código de Ética dos Profissionais de Enfermagem quanto na Lei do Exercício Profissional e legislação pertinente.

Para efeito de análise, utilizamos a informação contida nas situações extraídas das entrevistas e o significado individual dos marcadores, conforme será descrito a seguir.

\subsection{Compreender o âmbito das ações da enfermagem na produção de serviço de saúde.}

Esse marcador se expressa na prática por compreender as finalidades e os objetivos das ações que realiza; compreender o seu trabalho como totalidade parte do trabalho de enfermagem e de saúde; reconhecer o âmbito e os limites da sua atuação profissional e agir de acordo com a legislação vigente.

Os valores, contra-valores, atitudes e sentimentos extraídos das situações vinculados a esse marcador foram: gratidão, responsabilidade, iniciativa, revolta, indignação, impotência, receio e surpresa. 
A análise do conteúdo dos discursos de algumas enfermeiras possibilitou a identificação da ausência de compreensão do social como determinante da ação de enfermagem, limitando-a ao aconselhamento psicológico e encaminhamento da resolução do problema para outras instâncias como conselho tutelar, entre outros. Foram também reveladas várias ordens de dificuldades dos profissionais como falta de interação com a família e do reconhecimento dessa interação como ação de seu âmbito de atuação profissional, julgamento do comportamento da clientela com base em preconceitos e não prestação de assistência aos demais membros da família. Os trechos reproduzidos a seguir possibilitam exemplificar essas afirmações:

"[...] fato que eu relatei demonstrou uma situação social. Eu sou enfermeira, então como enfermeira eu fiz o que eu poderia, que seria encaminhar para uma ajuda psicológica. Ficou faltando a parte social, o que faríamos para ajudar nesta parte social."

"As crianças sofrem maus tratos, nasceram com baixo peso, ela não quis amamentar, é irresponsável, é usuária de drogas, passa as noites fora, deixa os filhos em casa junto com a mãe que teve um AVC e é acamada. A gente já tentou várias vezes acionar o Conselho Tutelar."

"Eu, como enfermeira, não sei até que ponto a gente pode interferir e fazer o que a família pede e até que ponto a gente pode julgar se ele não se acha etilista"

"Foi interessante, por que não é uma coisa de rotina [...] que acontece [...] a gente ter que contar para a família".

O conceito de família pode abranger diferentes aspectos entre eles o social, o cultural e o religioso, resultando em um amplo número de definições. Segundo Ângelo e Busso (2001), é fundamental que uma definição de família seja adotada e partilhada pelos membros da equipe de saúde. As autoras consideram família como

[...] um sistema ou uma unidade cujos membros podem ou não estar relacionados ou viverem juntos, pode conter ou não crianças sendo elas de um único pai ou não. Nela existe 
um compromisso e um vínculo entre os seus membros e as funções de cuidado da unidade consiste em proteção, alimentação e socialização (Angelo, Busso, 2001, p. 14).

As autoras referem, ainda, que a perspectiva que dá sentido ao processo de trabalho da estratégia Saúde da Família é tomar a família como unidade de cuidado. Assim, o processo de trabalho apresenta, entre outras, as seguintes características:

- está voltado à experiência da família ao longo do tempo, ou seja, considera a sua historia pregressa, atual e se preocupa com o futuro do grupo familiar;

- é dirigido a toda a família, incluindo os membros sadios e doentes pois que o sistema familiar é influenciado por qualquer mudança de seus membros;

- considera os contextos da cultura e da comunidade na facilitação das relações entre a família e a comunidade;

- implica no profissional interagir com a família.

Assim, desconsiderar a família como unidade de cuidado é um procedimento contrário ao processo de trabalho preconizado pela estratégia Saúde da Família e pela Política Nacional de Atenção Básica que estabelece a Saúde da Família como a forma principal por meio da qual se pretende chegar à reorientação do modelo de atenção (Brasil, 2006).

Em outra narrativa, verificou-se que a profissional apresentava dificuldade em reconhecer o limite da sua ação individual e falta de competência para lidar com algumas situações, refletindo uma visão individualizada da assistência. Frente aos seus limites, a enfermeira 
remete a responsabilidade pelo atendimento do usuário ao médico, identificando-o como "autoridade maior", com poder para lidar e resolver a situação.

"Eu fiz um relatório - foi a conduta que eu tomei - para gravidez de alto risco, para a doutora que é responsável por dar assistência da região sul todinha."

"Estou acompanhando de longe, mas eu não tenho como me aproximar dela. Foi uma atitude que eu tive que tomar porque eu não consegui resolver, tive que entregar nas mãos de uma autoridade maior para estar resolvendo esse problema."

A subordinação da enfermeira ao médico é um tema freqüentemente presente no meio profissional, provocando alguns incômodos nas relações estabelecidas entre esses profissionais. De acordo com Almeida (1997), as relações de poder entre os profissionais, principalmente entre médicos e enfermeiras, podem ser explicitadas claramente ou estar presente de inúmeras formas subliminares, permeando o conjunto das relações que se dão nos espaços de trabalho.

As situações apontaram, em alguns momentos, que o fazer da enfermeira é algo diferente do que ela está fazendo, porém não deixam clara a qualidade dessa diferença. Demonstram, com isso, incompreensão dos objetivos e do âmbito das ações que executa.

$\mathrm{O}$ aspecto religioso também apareceu de forma contraditória, ora a formação cristã sendo indicada como parte da formação profissional, ora excluida. A religiosidade foi expressa como abafadora de tensões, fortemente ancorada na visão idealista de mundo. Essa constatação indica a presença, ainda, das origens da enfermagem que tinha suas ações confundidas com sacerdócio. É importante salientar que 73,3\% dos profissionais participantes do estudo tiveram formação acadêmica em uma escola adventista, o que 
leva a crer que tal formação tem estimulado o exercício dos valores religiosos durante a ação da enfermagem. Na fala a seguir percebe-se claramente que a enfermeira optou por inserir orientação religiosa durante a assistência, como recurso para potencializar a ação da enfermagem.

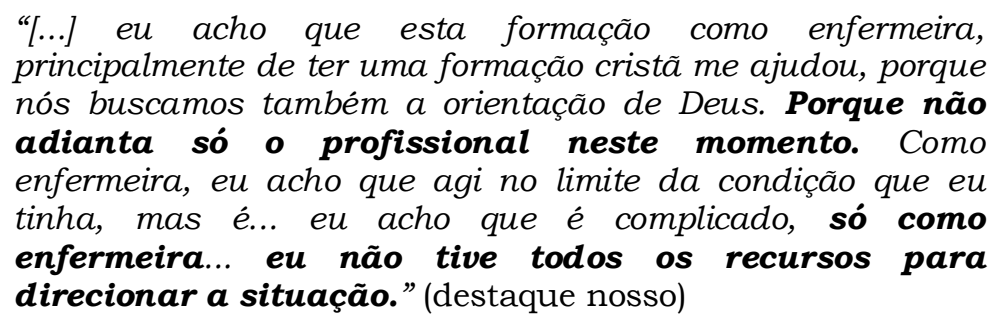
principalmente de ter uma formação cristã me ajudou, porque nós buscamos também a orientação de Deus. Porque não adianta só o profissional neste momento. Como enfermeira, eu acho que agi no limite da condição que eu tinha, mas é... eu acho que é complicado, só como enfermeira... eu não tive todos os recursos para direcionar a situação." (destaque nosso)

O cuidado prestado pela enfermagem passou a ser tido como sacerdócio após o advento do cristianismo. Nesse período, o cuidado dos enfermos era uma das formas de caridade adotadas pela igreja. À época, com a pregação de princípios como fraternidade, caridade e auto-sacrificio, os agentes de enfermagem, geralmente pessoas ligadas à Igreja, acreditavam que atendendo aos pobres e enfermos estariam salvando a alma e conquistando a vida eterna (Almeida, 1989).

Segundo Padilha (2005, p. 724) "a caridade era o amor a Deus em ação, propiciando para aqueles que a praticavam o fortalecimento de caráter, a purificação da alma e um lugar garantido no céu".

Mediante isto, o cuidado prestado aos enfermos elevou-se a um plano superior, uma vez que antes era um trabalho praticado por servos e converteu-se em uma vocação sagrada passando a ser integrado por homens e mulheres cristãs, especialmente estas últimas (Padilha, 2005). 


\subsection{Mobilizar saberes para avaliar contextos e tomar decisões}

A manifestação desse marcador no cotidiano das práticas de enfermagem consiste em relacionar o conhecimento e a experiência profissional com o contexto para enfrentar as situações, avaliando $e$ propondo ou adotando soluções.

Articulados a este marcador, apareceram como valores, atitudes e sentimentos compaixão, respeito, solidariedade, iniciativa, prudência e impotência.

A impotência se manifestou em várias situações, vinculada à assistência com base no conhecimento do senso comum. Num dos casos, a enfermeira recorreu unicamente à religião como forma de apoio e ajuda à usuária. A fala explicita claramente o que sentiu e o que fez.

"[...] eu senti impotência diante disso [...]. Eu não poderia recolher a menina na minha casa, não sou assistente social, não saberia para onde direcionar. O que eu podia fazer no momento ali eu acho que eu fiz, que foi encaminhar e orar com a mãe."

"[...] e oramos, porque 'nesta situação, mãe, precisa muito de Deus para te ajudar, precisa de apoio psicológico, mas também precisa desta parte espiritual. Você precisa pedir para ele colocar amor no seu coração, porque você precisa para a sua filha. Ela pode ser difícil, mas será que não é isto que está faltando? "

A expressão da profissional também sugere que ela entende o cuidado dos filhos como atribuição exclusiva da mulher. Cabe frisar que durante toda a entrevista não houve a menção da figura paterna. Além da naturalização da função social da mulher, isto se vincula fortemente ao mito do amor materno, ou seja, a maternidade deve 
sempre expressar o amor como obrigação da mãe em relação aos filhos. Sobre esse tema Badinter (1985, p. 2) considera que:

\begin{abstract}
O amor materno não constitui um sentimento inerente à condição de mulher, ele não é um determinismo, mas algo que se adquire. Tal como o vemos hoje, é produto da evolução social desde princípios do século XIX, já que, como o exame dos dados históricos mostra, nos séculos XVII e XVIII o próprio conceito do amor da mãe aos filhos era outro: as crianças eram normalmente entregues, desde tenra idade, às amas, para que as criassem, e só voltavam ao lar depois dos cinco anos. Dessa maneira, como todos os sentimentos humanos, ele varia de acordo com as flutuações socioeconômicas da história.
\end{abstract}

Essa convicção, de obrigação da mãe em relação aos filhos, se dá basicamente por duas razões. A primeira é devida à imposição feita pela cultura, responsável pelo desenvolvimento do modelo de amor materno conhecido atualmente e com o qual temos convivido desde o século XIX. A segunda, em uma relação de causalidade circular com a anterior, deve-se à necessidade de se idealizar a relação mãe-filho, idealização que obedece ao desejo de união perfeita, fantasia de completude que protege o indivíduo das ansiedades e medos mais primitivos de separação, abandono e perda. Desse modo, a mãe é concebida como alguém puro a quem são atribuídos apenas sentimentos nobres de acolhimento, abrigo e continência no que diz respeito a sua cria (Badinter, 1985).

O foco deste marcador é a identificação de atitudes que possibilitem a articulação da formação e da experiência profissional com a finalidade de propor ou adotar soluções para o enfrentamento das situações apresentadas no cotidiano do trabalho da enfermagem.

Nas narrativas, as enfermeiras dimensionam que a formação profissional é essencial para que a assistência prestada seja realizada com responsabilidade e cientificidade, além de possibilitar a 
compreensão e intervenção na realidade. Um aspecto interessante que surgiu foi o valor significativo depositado da formação profissional que ocorre para além da dimensão do saber-saber. Ou seja, que além do saber-saber, as demais dimensões, do saber-fazer e sobre tudo o saber-ser, são de importância impar para o enfrentamento de determinadas situações, como podemos observar nos trechos abaixo:

\begin{abstract}
“A formação profissional influenciou cem por cento. Estudei muito a respeito da criação de vínculos, relacionamento, humanização e isto ajuda muito a não desistir do paciente simplesmente pelo fato dele não querer o tratamento, não querer contato imediato com o serviço de saúde. Ajudou a abrir a mente no sentido de entender a diversidade da população $e$ as diversas formas que as pessoas nos apresentam" (grifo meu).
\end{abstract}

"A formação profissional dizia que eu tinha que ter tomado essa decisão bem antes disso, que eu deveria ser mais racional, não ponderar tanto. Mas devido à personalidade mais humana, a gente demora um pouco."

É importante registrar que esta verificação está em consonância com a formação inicial em enfermagem, uma vez, que essa formação, tem um papel essencial no desenvolvimento de competências profissionais. As Diretrizes Curriculares Nacionais (DCNs), em vigor desde 2001, reafirmam a necessidade e o dever das Instituições de Ensino Superior de formar profissionais de saúde para o SUS, com a finalidade de adequar a formação às necessidades de saúde da população brasileira (Leonello, 2007b).

Para Leonello (2007b), no campo da saúde, especialmente no que se refere à formação profissional, os quatro pilares da educação permitem compreender que a construção de competências implica articular diferentes saberes para a construção de uma prática profissional pautada não somente na aquisição e incorporação de conhecimentos e habilidades, mas também em atitudes pessoais e relacionais. 
Assim sendo, fica evidenciada a importância da dimensão do saber-ser para o desenvolvimento das práticas de enfermagem, como pode ser constatado no estudo desenvolvido por Leonello (2007a), que buscou a elaboração de competências para enfermeiras da atenção básica. A dimensão do saber-ser foi ressaltada por todos os sujeitos da pesquisa e, entre outros elementos, nessa dimensão, a autora reconhece que as enfermeiras necessitam de:

\begin{abstract}
Reconhecer-se como agente de transformação da realidade; assumir responsabilidade sobre a própria aprendizagem; construir sua identidade como pessoa e como enfermeira; perceber-se e compreender- se como ser humano; relacionar-se com sujeitos e grupos de diferentes condições socioeconômicas; reconhecer o outro; dialogar com os parceiros de trabalho; reconhecer e respeitar a autonomia dos usuários. (Leonello, 2007a, p.53)
\end{abstract}

E, por fim, nesse marcador, houve identificação de um momento de superação, onde a profissional reconhece que o aprendizado obtido na vivência da situação trouxe subsídios para uma atuação proativa em ocasiões similares:

\footnotetext{
"Hoje acho que se voltasse a acontecer, tomaria uma atitude diferente como enfermeiro, corria atrás, ligaria para onde fosse, ligaria para supervisão, para tentar agilizar um diagnóstico para passar num especialista, estar fazendo um exame mais detalhado. A demora foi grande, a experiencia me adiantaria para não demorar tanto tempo" (grifo nosso)
}

\title{
5.3 Interagir com o usuário e seus familiares, demonstrando atenção às várias formas de manifestação de suas necessidades e demandas.
}

Esse marcador tem sua expressão através da compreensão da linguagem verbal do usuário, percebendo, ouvindo e compreendendo as razões que motivam suas atitudes e comportamentos. Esta interação se expressa na adoção de principios e valores como: bondade, compaixão, cooperação, empatia, generosidade, honestidade, 
humanidade, iniciativa, justiça, lealdade, respeito, solidariedade e tolerância.

Os sentimentos, valores e atitudes identificados nas entrevistas foram: compaixão, iniciativa, tolerância, solidariedade, persistência, impotência, generosidade, medo e receio.

Em duas situações, na interação da enfermeira com os usuários e as famílias, pode-se observar que apesar de perceber as razões que motivaram as atitudes dos usuários, ela não agiu de acordo com as necessidades detectadas, ou seja, não realizou a denúncia da violência doméstica. Isso ocorreu não por desconhecimento da profissional do seu dever, mas por medo de sofrer represálias ou mesmo violência física por parte dos usuários ou familiares.

"Ele é um rapaz que faz uso de drogas e fica difícil para gente. Você vai se envolver com alguém que você sabe que é traficante e ele age de uma forma violenta."

"Até onde a gente pode se envolver nesta questão de agressão de violência entre familiar? Porque a gente vai acabar se prejudicando e eles acabando bem porque se amam."

"Isso que preocupa, porque a menor atitude que a gente toma já pode ter uma represália, a gente não sabe lidar ainda como se deve. No primeiro momento, o que a gente sente é revolta."

A literatura consultada apresenta a violência doméstica como uma situação invisível e complexa, no entanto, presente e recorrente nos serviços de saúde, de difícil abordagem. Além disso, os serviços de saúde, que em sua maioria, não têm condições técnica e organizacionais de atender essa demanda específica e os profissionais de saúde se sentem incapazes de lidar com um problema tão complexo (Andrade, Fonseca, 2008). 
Segundo Morvant (2007) a maioria dos profissionais de saúde não enxerga o sofrimento da mulher relacionado à violência sofrida, antes, "muitos preferem ficar passivos em face das violências ou no encontro de situações dificeis de gerenciar. Eles têm o sentimento de ficarem isolados, impotentes e com medo de recorrer à lei". Constatou-se que muitos profissionais ainda se encontram despreparados para tratarem do tema da violência com suas pacientes e muitos ainda se sentem inseguros em lidar com um assunto que envolve emoções e sentimentos relacionados a essa temática.

Oliveira e Fonseca (2006) identificaram em seu estudo relacionado às práticas dos profissionais da equipe saúde da família voltadas para mulheres em situação de violência sexual que a tentativa de resolução dos problemas referentes à agressão física à mulher, na singularidade da ação do profissional de saúde ou no nível da atenção básica, inviabiliza a efetividade da ação prestada. Para as autoras tal posição indica

[...] o receio que o profissional sente ao atuar quando o assunto é violência contra a mulher. Aparentemente a estrutura do serviço não tem um setor organizado para esse trabalho, tanto preventivo como curativo. A atitude do profissional acaba sendo de afastamento ou negação. (Oliveira e Fonseca, 2006, p. 608)

Oliveira e Fonseca (2006, p. 611) concluem que

Os profissionais consideraram que a sua atuação é caracterizada por uma impotência paralisante que pode ser atribuída à falta de preparo, de organização do processo de trabalho e aos valores sociais que são absorvidos de forma sutil através da história de vida de cada sujeito e do grupo como um todo. Ao atenderem mulheres em situação de violência sexual os profissionais que integram as equipes de saúde da família definem sua atuação como de impotência paralisante que consideram como um reflexo da falta de organização do serviço para este fim. 
Outro ponto relevante, apresentado nos trechos destacados para esse marcador, foi a necessidade de criação de vínculo entre os profissionais de saúde e a clientela, com os objetivos de identificar e atender as necessidades de saúde apresentadas.

"Muitas famílias tinham má impressão exatamente porque o agente não conseguia chegar, não era recebido, mas depois do primeiro contato, da gente estar mais próximo, levando o resultado do exame, conversando, explicando um pouquinho como funciona nosso programa, eles passaram a atender melhor o agente de saúde e o relacionamento também com o posto mudou muito."

"Um dia ela estava aqui no posto e tentei convencê-la a colher o Papanicolau. Falei que era eu mesma que ia colher, para ela ficar tranqüila, que ninguém estaria vendo e depois de muito tempo a convenci."

"Prestei o primeiro atendimento assim que ela chegou na unidade e depois fique como referência, ela não acreditava mais no médico não acreditava mais em ninguém. Em decorrência disso, criei um vínculo muito grande."

A taxonomia de necessidades de saúde sugerida por Cecilio (2006) é organizada em quatro grandes conjuntos de necessidades. O primeiro diz respeito a se ter "boas condições de vida"; o segundo à necessidade de se ter acesso e de se poder consumir toda a tecnologia capaz de melhorar e prolongar a vida; um terceiro fala da necessidade de cada pessoa ter graus crescentes de autônima no seu modo de levar a vida; e o quarto e último conjunto de necessidades dizem respeito “...à insubstituível criação de vínculo (a)efetivo entre cada usuário e uma equipe/profissional - vínculo enquanto referência e relação de confiança” (Cecilio, 2006, p. 117).

Para o autor, o fundamental é reconhecer que:

O vínculo, mais do que a simples adscrição a um serviço ou inscrição formal de um programa, significa o estabelecimento de uma relação contínua no tempo, pessoal e intransferivel, calorosa: encontro de subjetividades. (Cecilio, 2006, p.117). 
Segundo Campos (1997), o vínculo com os usuários do serviço de saúde amplia a eficácia das ações de saúde e favorece a participação do usuário durante a prestação do serviço. Esse espaço deve ser utilizado para a construção de sujeitos autônomos, tanto profissionais quanto pacientes, pois não há construção de vínculo sem que o usuário seja reconhecido na condição de sujeito, que fala, julga e deseja.

\subsection{Perceber, compreender e respeitar-se como cidadão e como trabalhador de saúde.}

O significado desse marcador é ter apreço para consigo mesmo e para com o próprio trabalho; reconhecer e exercitar seus direitos, sua autonomia e auto-desenvolvimento; respeitar os seus próprios sentimentos, atitudes e valores éticos-morais considerando o bem-estar e os direitos dos usuários.

Apenas em duas narrativas foi possivel a identificação de falas referentes a esse marcador. Os valores e sentimentos que emanaram foram responsabilidade, impotência e incompetência.

O sentimento de impotência surgiu relacionado ao fato da profissional não ter atuado de maneira ágil para a resolução de uma situação. Já o da incompetência apareceu no momento em que a enfermeira verbaliza que a iatrogenia "jamais poderia ter ocorrido com ela".

\footnotetext{
"Naquele momento senti o pior do ser humano, aquilo me comoveu profundamente, me senti incompetente, me senti [...] um lerdo. Foi algo que jamais poderia acontecer comigo."

"Após o óbito do paciente não consegui realizar visitas à familia, pela dificuldade que tivemos de encaminhar o mais rápido possivel, que pudesse levar a um diagnóstico que não causaria a morte com tanta rapidez."
} 
Não foram observados nas situações trechos significativos, dificultando a análise da potencialidade do marcador para as enfermeiras da UBS. Por ser um marcador relacionado a perceber, compreender e respeitar-se como cidadão e trabalhador, identifica-se a dificuldade das profissionais em se perceberem como sujeitos de direito. Isso pode ser decorrente do fato de 93\% dos sujeitos da pesquisa serem mulheres associado a uma Enfermagem como trajetória histórica recheada de momentos onde seu exercício se dava por mulheres desqualificadas para a sociedade da época (Fonseca, 2002).

\subsection{Demonstrar responsabilidade para com usuários e equipe nas situações de trabalho}

Corresponde à maneira subjetiva que cada trabalhador apreende as situações de trabalho e se situa em relações a elas, dimensionando as ações que são necessárias para enfrentá-la. A responsabilidade se expressa pelo compromisso e reciprocidade (interação) entre as pessoas envolvidas com um conjunto de ações, em prol da qualidade da assistência.

O cumprimento das tarefas como responsabilidade profissional, a (des) responsabilização, responsabilidade, persistência, impotência, receio, compaixão e compromisso foram os sentimentos e valores articulados a este marcador.

As falas possibilitaram perceber o compromisso das enfermeiras com a realização das ações e o entendimento das situações em que estão inseridas para além do dimensionamento das ações necessárias para o enfrentamento das dificuldades, compreendendo as possiveis implicações que possam ocorrer.

"Várias vezes foi solicitado pela agente de saúde para colher o Papanicolau e passar em consulta. Chegávamos a agendar a consulta ela não vinha. Fui umas duas vezes na casa dela 
para tentar convencê-la, porque ela se queixava de dor, mas ela nunca procurava o médico, não vinha nas consultas agendadas."

"A gente fica se perguntando não só nesse caso, mas em outros casos com bebê, com conselho tutelar - que a gente sente vontade de chamar - mas temos um monte de limitações. Isso é uma coisa que temos tentado desenvolver, tem bastante casos, a gente fica meio de mãos atadas, acabamos nos comprometendo, nos colocando em evidência e depois ter a represália da própria população, que acha que a gente quis prejudicar."

Em outro caso, a enfermeira compreendeu sua responsabilidade de levar em conta a religiosidade da usuária, percebendo a importância das questões religiosas e adequando suas ações no sentido de realizar corretamente as orientações necessárias. Identificou ainda a dificuldade em lidar com a diversidade cultural.

"É duro falar e lidar com as crenças das pessoas. Vou a casa dela, vejo que é bastante religiosa, tem suas crenças, então trabalhar isso é complicado. Mas você tem que tentar orientar conforme aquilo que ela acredita. Tem um tabu e uma barreira muito grande."

Um aspecto importante observado em uma das situações foi a (des) responsabilização, ou seja, a profissional entendeu que sua responsabilidade acabou quando ela transferiu o caso para outra instância. Neste caso, o que embasou a ação foi um contra-valor.

"Liguei para ela, mandei carta, mandei e-mail e tirei a responsabilidade de mim, porque não tenho o que fazer."

Outro ponto de relevância foi a verificação do compromisso da enfermeira com a execução de sua tarefa, acima do compromisso com o bem-estar da paciente. Para ela, o importante era cumprir a atividade de acompanhamento e monitoramento da gestante de sua área de abrangência, caso contrário, poderia ser chamada a atenção.

"Ela é responsabilidade nossa porque se acontece alguma coisa com a grávida, eles vêm em cima cobrar: por que você não foi atrás, cadê a participação do médico, cadê isto? $E$ eu fico preocupada até quando ela vai ganhar. Eu acho que está 
previsto para o mês que vem, quase final de agosto $e$ enquanto ela não ganhar, a gente, eu particularmente, não vou sossegar, eu fico muito preocupada. Então, se ela não vem na consulta eu vou atrás, vou à casa dela. Então é até ela ganhar mesmo, passar a fase do puerpério e aí, pronto."

As situações levantadas nos remetem aos aspectos relacionadas a responsabilidade profissional especialmente no que se refere ao cumprimento do Código de Ética dos Profissionais de Enfermagem, revelando o predomínio de uma postura ética tanto deontológica, baseada no cumprimento de deveres, quanto utilitarista, voltadas para o resultado das práticas. Como resultado o que se percebe é uma visão pouco reflexiva sobre suas práticas, assim como o não reconhecimento da necessidade e do direito do usuário.

Por outro lado, cabe ressaltar que nenhum código de ética profissional consegue abranger todos os dilemas éticos vivenciados durante as práticas profissionais (Oliveira, 2001).

\subsection{Interagir com a equipe de trabalho de acordo com os valores que regem o trabalho da enfermagem}

Pressupõe articular-se com a equipe de trabalho, num movimento de solidariedade $e$ de compartilhamento, assumindo coresponsabilidade e reconhecimento das competências dos outros. Visa ao eficaz resultado das ações e procedimentos que realiza.

Somente em uma entrevista foi possivel a identificação de um trecho capaz de expressar o significado desse marcador. A atitude que emergiu foi a liderança da enfermeira diante da equipe de enfermagem. 
$\mathrm{Na}$ estratégia Saúde da Família, a prática de enfermagem se insere buscando a reformulação e a integração de ações com os demais trabalhadores da equipe de saúde.

O trabalho desenvolvido pelas enfermeiras nestas unidades é realizado de forma diversificada, abrange o cuidado da enfermagem prestado ao indivíduo, família e grupo populacional, que mora ou trabalha na área geográfica de sua abrangência, passando pelas ações educativas, gerenciais e a participação no planejamento em saúde.

Liderança em enfermagem pode ser entendida com um processo por meio do qual a enfermeira influencia as ações de outros para o estabelecimento e para o alcance de objetivos. Isto implica definir e planejar a assistência de enfermagem num cenário interativo (Trevizan, 1998).

A autora enfatiza que a liderança exercida pelo enfermeiro necessita ser democrática ou criativa, já que a idéia que subjaz a esta organização de assistência é o trabalho conjunto de uma equipe que atua como um grupo democrático (Trevizan, 1998).

Para Araújo (2003, p. 116):

[...] o enfermeiro exerce um papel preponderante [no trabalho de enfermagem na estratégia Saúde da Família], desde o planejamento das ações até a assistência, o que torna sua ação diferente daquela que ocorre em instituições estruturadas no modelo tradicional.

Hilda e Trevizan (2005, p.59) defendem a idéia de que:

[...] a enfermagem precisa de líderes comprometidos e motivados para direcionar o desenvolvimento dos processos 
de trabalho com foco na necessidade dos pacientes/clientes, que sejam capazes de estruturar humanamente o desenvolvimento científico e tecnológico, fundamentando-se na consciência ética e em prol da capacidade de criação do homem.

Estudos recentes demonstram que entre as habilidades de liderança necessárias para o adequado desenvolvimento das ações de enfermagem as seguintes merecem destaque: conhecimento, experiência, confiança, capacidade de trabalhar em equipe, de solucionar problemas, autodesenvolvimento, relacionamento interpessoal, comprometimento e respeito entre a equipe e saber ouvir. (Hilda e Trevizan, 2005)

Portanto, entendemos que entre os requisitos básicos para atuação das enfermeiras na unidade básica de saúde, fica evidente que elas precisam apresentar capacidade de liderança e saber trabalhar em equipe.

\subsection{Respeitar os direitos dos usuários como cidadãos}

Compreender que os usuários têm direito à assistência de qualidade. Compreender que a saúde é um direito do usuário como cidadão brasileiro e um dever do estado. Reconhece a autonomia do usuário em relação à sua própria saúde.

Para esse marcador foram observados como valores a solidariedade, persistência, responsabilidade e respeito. Como sentimento surgiu a impotência e como contra-valores o autoritarismo e negação da fraternidade entre as mulheres.

As enfermeiras apresentavam compromisso com a realização das ações levando em consideração o bem-estar dos usuários; reconheciam o usuário como sujeito social inserido numa família, possuidor de necessidades e de sonhos; compreendiam que as 
práticas de saúde devem ser realizadas para além da dimensão do saber biológico e respeitavam a autonomia dos usuários e dos familiares. Essas atitudes podem ser observadas nos trechos abaixo:

\begin{abstract}
"Hoje eu me sinto mais segura frente a outros casos semelhantes, deu um pouco mais de estabilidade para compreender que nem todas as pessoas aceitam $e$ querem o serviço de saúde tão próximo".
\end{abstract}

"[...] a família que veio até nós pedindo ajuda e na verdade a gente não acha que é nosso dever ajudar da forma como a família queria, não dá para ajudar mais do que orientar $e$ conversar com ele, mas se ele não se sente, não acha que é etilista, é complicado a gente agir sobre isto."

"A gente procura ver não só o indivíduo, mas a família toda. Acho assim, que a gente procura ver a questão social, todo o meio onde o usuário vive, toda a história dele."

"[...] toda essa dinâmica do processo saúde doença de ver a pessoa como um todo, entender o contexto da vida dela porque ela está assim... $e$ isso foi fundamental. Principalmente para gente entender que ele faz parte de um processo, uma familia, que tem sonhos, projetos, necessidades, tem tantas coisas e não é só uma ferida que ele tem. Até para motivar a gente a continuar, entender todo esse processo é essencial."

Neste marcador, os contra-valores surgiram expressos pela visão biologicista do processo saúde-doença, levando à não identificação das demais necessidades de saúde e demandas da clientela. Isto, por sua vez, resultou na imposição de condutas e na desconsideração da autonomia do usuário sobre o seu próprio processo de saúde-doença. Do ponto de vista da produção de saúde, ocorreu a valorização da produção de procedimentos em detrimento da produção de cuidados.

"A minha formação me direcionou para isso: se eu encontrei um paciente que está rebelde no tratamento, que está resistente é tentar convencê-lo a se cuidar com as informações que eu tenho sobre aquela doença, sobre as conseqüencias daquela doença, a poder controlar melhor aquela doença." 
"Ela tem que tomar vacina Rogan, porque ela é Rh Negativo, mas a gente encaminha e ela não vai. Falou que nas outras gravidezes ela tomou na hora do parto por isto vai deixar para tomar esta na hora do parto. A gente fica preocupada, mas ela continua dizendo que só vai tomar no hospital (...). Mas eu vivo falando para ela que ela tem que parar de fumar e tem que ficar mais de repouso, mas ela leva a gravidez de qualquer jeito."

Matumoto (2005, p. 11) enfatiza que

\begin{abstract}
Uma ação de saúde centrada na lógica da produção do procedimento irá se constituir somente pelos elementos que lhe são próprios, como por exemplo, consultas, visitas domiciliares, aplicações de vacinas ou curativos (...). Os procedimentos passam a ser a finalidade última do trabalho e, assim, configura um modelo que é contraditório com a missão do próprio SUS: o cuidado.
\end{abstract}

Para a autora:

A ação de saúde centrada na lógica da produção do cuidado traduz-se no trabalho orientado aos problemas, às necessidades e à qualidade de vida do usuário. São ações que, além de produzir os procedimentos inerentes ao caso, como uma sutura, uma consulta ou um curativo, por exemplo, centram atenção nas relações humanas, na produção de vínculo, no acolhimento (Matumoto, 2003), na autonomia do usuário no cuidado de si. (Matumoto, 2005, p. 12)

O poder exercido pelo saber das profissionais como forma de dominação dos usuários por meio do convencimento para a adesão ao tratamento foi outro contra-valor observado nas entrevistas. Isto ficou explícito vinculado a uma questão de gênero: o não reconhecimento, por parte da enfermeira, da autonomia da usuária em relação aos seus direitos reprodutivos. O que houve foi imposição da profissional para que a usuária - pobre e já com muitos filhos passasse a utilizar uma medida contraceptiva.

"Fico orientando, incentivando ela a participar do planejamento familiar. Já foi em duas reuniões e eu estou querendo que ela vá à terceira porque se não colocar o DIU, não laquear... Que pelo menos coloque o DIU, porque as crianças ficam sofrendo [...]. A gente se comove mais pelo lado das crianças." (grifo nosso) 
A fala a seguir explicita claramente a aderência da profissional à ideologia controlacionista como medida para sanar a pobreza, além do julgamento da enfermeira em relação à obrigatoriedade da mulher de cuidar dos filhos, mantendo-os limpos. Da mesma maneira, percebe-se o julgamento moral em relação à doação e a desconsideração da companhia da filha mais velha como possivel superação da falta de companhia de outras pessoas.

\footnotetext{
"A mais velha está com o pai e a outra fica para cima e para baixo com ela [...]. Vem aqui no posto de qualquer jeito, não tem higiene adequada, nem com ela $e$ nem com as criancinhas, é meio desligada [...]. Ela estava até falando que ia dar este último nenê, mas não sei se é verdade."
}

\subsection{Compreender e posicionar-se frente às condições de trabalho existentes nas instituições}

Compreender e posicionar-se em relação aos efeitos da organização $e$ das condições de trabalho sobre os trabalhadores, usuários e sobre o próprio processo de trabalho em saúde.

Sentimentos e valores de impotência, iniciativa, responsabilidade foram encontrados nas situações descritas pelas enfermeiras da unidade básicas de saúde.

Os trechos identificados apontam para a compreensão dos efeitos da organização e das condições de trabalho, tanto sobre os trabalhadores como para os usuários, quando da referencia à morosidade nos encaminhamentos, nos processos de agendamento com especialistas e nas dificuldades para a obtenção de transporte de pacientes, trazendo adversidades ao atendimento das necessidades de saúde do usuário. 


\begin{abstract}
"No mesmo dia, a gente tentou agendar consulta para ela estar fazendo toda esta parte desta especialidade que é uma coisa mais burocrática aqui no posto." (grifo meu)
\end{abstract}

"[...] achamos uma ambulância aqui na supervisão do Campo Limpo, porém estava quebrada. Ligávamos para a supervisão atrás da ambulância e não conseguíamos, era corrida contra o tempo a favor da vida de uma pessoa, se ela não conseguisse dialisar, ela ia morrer."

No entanto, é mais perceptivel o sentimento de indignação quanto às situações vivenciadas, do que propriamente o posicionamento frente às condições de trabalho existentes nas instituições.

Por outro lado, os sentimentos de impotência, iniciativa e responsabilidade apresentados pelas enfermeiras nas situações relatadas estão fortemente vinculados aos limites de sua atuação profissional, visto ser esta mediada por rotinas e condutas que muitas vezes desconsideram as reais necessidades de saúde da população e as especificidades do processo de trabalho em saúde local.

Considerando o exposto, observou-se que os valores presentes nas situações descritas pelas enfermeiras das unidades básicas de saúde são os mesmos que foram identificados quando da pesquisa intitulada "As práticas de enfermagem e as competências do saberser" (Fonseca et al, 2006), por meio da qual foram desenvolvidos marcadores do saber-ser ético-profissional para o auxiliar de enfermagem. Por conseguinte, isto nos permite afirmar que também os marcadores desenvolvidos para os auxiliares de enfermagem são passiveis de serem aplicados às práticas das enfermeiras, como pode ser percebido nos relatos. 


\section{Considerações finais}

Este estudo partiu do pressuposto de que a competência profissional se expressa nas práticas de trabalho e sendo assim, buscou investigar como se expressa a dimensão do saber-ser éticoprofissional das enfermeiras nas práticas profissionais em uma unidade básica de saúde.

Por meio do reconhecimento de situações do cotidiano dessas profissionais foi possivel identificar os elementos relacionados a essa dimensão da competência profissional bem como verificar a aplicabilidade dos marcadores identificados para o profissional auxiliar de enfermagem nas ações desenvolvidas pelas enfermeiras em seu espaço de atuação.

Os valores que emergiram das situações apresentadas pelas enfermeiras são similares aos identificados na pesquisa "As práticas de enfermagem e as competências do saber-ser" realizadas junto aos auxiliares de enfermagem no âmbito do projeto SCC/Profae, que foram: compreensão, respeito, solidariedade, responsabilidade, generosidade, bondade, tolerância, honestidade, lealdade, união, humildade, cooperação, compaixão, justiça, autonomia, iniciativa e empatia.

Quanto aos marcadores do saber-ser ético-profissional formulados para os auxiliares de enfermagem, todos apresentam potencialidade para representar o saber-ser ético-profissional das enfermeiras da unidade básica de saúde, especialmente no que concerne à sua aplicabilidade nas práticas de enfermagem realizadas.

Do total de oito marcadores, verificamos que cinco estiveram mais evidentes nas situações analisadas, a saber: compreender o 
âmbito das ações da enfermagem na produção de serviço de saúde; mobilizar saberes para avaliar contextos e tomar decisões; interagir com o usuário e seus familiares, demonstrando atenção às várias formas de manifestação de suas necessidades e demandas; demonstrar responsabilidade para com usuários e equipe nas situações de trabalho e; respeitar os direitos dos usuários como cidadãos.

O marcador referente a compreender o âmbito das ações da enfermagem na produção de serviço de saúde revelou a ausência de compreensão do social como determinante da ação de enfermagem, assim como a incompreensão dos objetivos e do âmbito das ações que executa. Quanto a interagir com o usuário e seus familiares, demonstrando atenção às várias formas de manifestação de suas necessidades e demandas, veio à tona a necessidade de criação de vinculo entre os profissionais de saúde e usuários, com o objetivo de identificar e atender as necessidades de saúde apresentadas.

O marcador relacionado à mobilização de saberes para avaliar contextos e tomar decisões apresenta como aspecto principal práticas de saúde baseadas no senso comum em desacordo com o reconhecimento da necessidade de se prestar assistência com cientificidade e responsabilidade.

Quanto aos marcadores demonstrar responsabilidade para com usuários e equipe nas situações de trabalho e respeitar os direitos dos usuários como cidadãos, foram embasados em contra-valores, cuja principal expressão foi a desresponsabilização. $O$ primeiro representado pela transferência de responsabilidade a outros membros da equipe ou outra unidade de saúde e pela valorização com a execução da tarefa, acima das reais necessidades do usuário; e o segundo foi evidenciado pela visão biologicista do processo saúde- 
doença, com a valorização da produção de procedimentos em detrimento da produção de cuidados.

Em relação os demais marcadores, embora as entrevistas tenham trazido um número pequeno de situações para uma análise mais consistente dos mesmos, foi possivel estabelecer algumas considerações. O marcador perceber, compreender e respeitar-se como cidadão e como trabalhador de saúde manifesta-se através do seu não reconhecimento, pelas profissionais, como sujeitos passiveis de cometerem erros e, ainda, como sujeitos de direito. Quanto a interagir com a equipe de trabalho de acordo com os valores que regem o trabalho da enfermagem, o que emergiu dos relatos foi a importância da liderança da enfermeira diante da equipe de enfermagem, com vistas ao alcance de objetivos comuns.

O marcador compreender e posicionar-se em relação aos efeitos da organização e das condições de trabalho sobre os trabalhadores, usuários e sobre o próprio processo de trabalho em saúde foi o menos expressivo nas situações relatadas. Os trechos trazem muito mais a indignação frente às situações vivenciadas do que propriamente um posicionamento frente às condições de trabalho existentes nas instituições. Cabe observar que a totalidade das entrevistadas desenvolve suas ações de enfermagem em atividades assistenciais, como visitas domiciliárias e consultas de enfermagem.

Os achados do presente estudo apontam para similaridades dos valores e marcadores que regem tanto a prática de auxiliares de enfermagem quanto de enfermeiras, o que podem ser entendido como um fator positivo, uma vez que os sujeitos das pesquisas representam duas categorias de uma mesma profissão. De outra forma, tais similaridades prenunciam a potencialidade que tais valores e marcadores possuem para representar o saber-ser ético-profissional 
não das categorias em separado, mas sim da profissão como um todo.

Outro aspecto importante, a nosso ver, é que os valores e marcadores identificados também denotam potencialidade para virem a ser considerados referências para o desenvolvimento da competência profissional na dimensão do saber-ser ético-profissional nos processos educativos dos profissionais de enfermagem e, especialmente, das enfermeiras, sejam eles no âmbito da formação ou da capacitação em serviço.

No entanto, a presente pesquisa também aponta para a necessidade de realização de outros estudos sobre este tema, principalmente na direção de uma validação dos marcadores junto a profissionais enfermeiras que possuem expertise em ética, ética profissional e nas áreas assistenciais, à semelhança do que foi feito na pesquisa com auxiliares de enfermagem.

Por fim, entendemos que pautar a discussão sobre a dimensão do saber-ser ético-profissional nos espaços onde acontecem as práticas de saúde (sejam elas na atenção básica ou nos demais níveis de assistência) e os processos educativos da enfermagem (sejam eles no âmbito das instituições formadoras ou serviços), é primordial para a construção de práticas de cuidado que favoreçam não só a transformação dos sujeitos (profissionais e usuários) envolvidos, mas o enfrentamento dos problemas de saúde na perspectiva do processo de saúde-doença numa visão histórica e socialmente determinada. 


\section{Referências}

Almeida MCP, Mishima SM, Silva EM, Mello DF. O trabalho de enfermagem e sua articulação com processo de trabalho em saúde coletiva: rede básica de saúde. In: Almeida MCP, Rocha SMM, organizadores. O trabalho de enfermagem. São Paulo: Cortez; 1997. p. 61-112.

Almeida MCP, Barreira IA. Os estudos de pós- graduação em enfermagem na América Latina: sua inserção na comunidade científica. In: Educación de Enfermería en América Latina. Red de Enfermería de América Latina/Universidad Nacional de Colombia, Facultad de Enfermería. Colômbia, 1989, p.129-145.

Andrade CJM, Fonseca RMGS. Considerações sobre violência doméstica, gênero e trabalho das equipes de saúde da família. Rev. Esc. Enfem. USP. 2008; 42(3):591-5

Angelo M, Bousso RS. Fundamentos da Assistência à Família em Saúde. In: Brasil. Ministério da Saúde. Universidade de São Paulo. Instituto para o Desenvolvimento da Saúde. Manual de Enfermagem. Brasília: Ministério da Saúde, 2001. p. 14-17.

Araújo MFS. Prática Profissional e Construção da Identidade do Enfermeiro no Programa de Saúde da Família [tese]. João Pessoal: Universidade Federal da Paraíba, 2003.

Ayres, JRCM. Cuidado e reconstrução das práticas em saúde. Interface Comunic., Saúde, Educ. 2004; 8 (14):73-92.

Badinter E. Um Amor Conquistado: o Mito do Amor Materno. Rio de Janeiro: Nova Fronteira, 1985.

Baraldi S. Supervisão, flexibilização e desregulamentação no mercado de trabalho: antigos modos de controle, novas incertezas nos vínculos de trabalho da enfermagem [tese]. São Paulo: Escola de Enfermagem da Universidade de São Paulo, 2005.

Bardin L. Análise de conteúdo. Lisboa; 1977.

Bellato R, Giva MAM. A cidadania e a ética como eixo norteadores da formação do enfermeiro. Rev. Bras. Enferm. 2003; 56(4):429-32.

Bobroff MCC. Identificação de comportamento de cuidado afetivoexpressivos no aluno de enfermagem: construção de instrumentos [dissertação]. São Paulo: Escola de Enfermagem, Universidade de São Paulo, 2003.

Boff L. Saber cuidar. Ética do humano - compaixão pela Terra. $7^{\text {a }}$ ed. Petrópolis: Vozes, 2001. 
Boff, L. Ética e moral: a busca dos fundamentos. Petrópolis: Vozes; 2003.

Boff. L. O cuidado essencial: princípio de um novo ethos. Inclusão Social [periódico na internet]. 2005; 1(1): 28-35. Disponivel em: http://revista.ibict.br/inclusao/index.php/inclusao/article/view/6 L11\#.

Bottomore, T. Dicionário do Pensamento Marxista. Rio de Janeiro: Jorge Zahar Editor; 1993.

Bourdieu P. Coordenador. A miséria do mundo. $5^{\text {a }}$ ed. Petrópolis: Vozes; 2003.

Brasil, Lei $\mathrm{n}^{\circ}$. 10.406, de 10 de janeiro de 2002. Dispõe sobre o Código Civil brasileiro. São Paulo: Saraiva, 2002.

Brasil, Ministério da Saúde. Secretaria de Gestão do Trabalho e da Educação na Saúde. Relatório final da validação do perfil de ações do auxiliar de enfermagem/PROFAE. Brasília (DF); 2001. Disponivel em: http://bvsms.saude.gov.br/bvs/publicações/perfil_açoes_aux_enf.pd f. Acessado em 10/05/2009.

Brasil. Conselho Nacional de Saúde Resolução n.196, de 10 de outubro de 1996. Aprova as seguintes diretrizes e normas regulamentadoras de pesquisas envolvendo seres humanos. Disponivel em http://conselho.saude.gov.br/comissao/conep/resolucao.html. Acessado em maio de 2009.

Brasil. Lei $\mathrm{n}^{\circ}$. 2.848, de 07 de dezembro de 1940. Dispõem sobre o Código Penal brasileiro. Disponível em http://www.edutec.net/Leis/Gerais/cpb.htm. Acessado em 30 de abril de 2009.

Brasil. Ministério da Saúde. Portaria GM 648, de 28 de março de 2006. Aprova a Política Nacional de Atenção Básica, estabelecendo a revisão de diretrizes e normas para a organização da Atenção Básica para o Programa Saúde da Família (PSF) e o Programa Agentes Comunitários de Saúde (PACS). In: Brasil. Ministério da Saúde. Política Nacional de Atenção Básica. Brasília; 2006. p. 7-51.

Brasil. Ministério da Saúde.Secretária de Gestão de Investimento em Saúde. Referencias conceituais para a organização do Sistema de Certificação de Competências Profae. Brasília; 2000. Disponível em http://bvsms.saude.gov.br/bvs/publicacoes/scc_referencias_conceit uais. Acessado em março de 2009.

Campos GWS. Considerações sobre a arte e a ciência da mudança: revolução das coisas e reforma das pessoas. O caso da saúde. In: 
Cecílio LCO, organizador. Inventando a mudança na saúde. $2^{\mathrm{a}}$ Ed. São Paulo: Editora Hucitec; 1997. p. 29-87.

Carvalho AC. Associação Brasileira de Enfermagem 1926-1976. Documentário. ABEN Brasília-DF. 1976.

Cecílio LCO. As necessidades de saúde como conceito estruturante na luta pela integralidade e eqüidade na atenção em saúde. In: Pinheiro R, Mattos RA, organizadores. Os sentidos da integralidade na atenção e no cuidado à saúde. Rio de Janeiro: Ed. Abrasco; 2006. p. 113-26.

CEInfo. Coordenação de Epidemiologia e Informação. São Paulo. Secretaria Municipal da Saúde; 2008. [Periódico Internet acessado em 11 de novembro de 2008]. Disponivel em: http://ww2.prefeitura.sp.gov.br//arquivos/secretarias/saude/painel _monitoramento/0006/INS_3edicao_Junho2008.pdf/.

Chauí M. O que é ideologia. 2a ed. São Paulo: Brasiliense; 2001.

Chauí MH. Convite à filosofia. São Paulo: Ed. Ática; 2000.

Coelho EAC, Fonseca RMGS. Repensando o cuidado na relação dialética entre sujeitos sociais. Rev Bras Enferm. 2005; 58(2): 214-7.

Compte-Sponville A. O Pequeno tratado das grandes virtudes. [via internet]. São Paulo: Ed. Martins Fontes; 1999. Disponivel em http://br.geocities.com/mcrost04/index.htm. Acessado em outubro de 2008.

Conselho Federal de Enfermagem. Aprova o Código de Ética dos Profissionais de Enfermagem e da outras providências. Resolução COFEN no 311/2007. Disponivel em http://www.portalcofen.com.br/2007/section.asp?sectionParentID=3 $\underline{4 \& \text { sectionID }=30}$. Acessado em 02 de maio de 2009.

Craco, PF. Ação comunicativa no cuidado à Saúde da Família: encontros e desencontros entre profissionais de saúde e usuários [tese]. Ribeirão Preto: Escola de Enfermagem da Universidade de São Paulo, 2006.

DATASUS. gov.[base de dados na Internet]. Brasília: Ministério da Saúde; 2009. Disponivel em: www.datasus.gov.br

Delors J, organizador. Educação: um tesouro a descobrir. $8^{a}$ ed. São Paulo: Cortez; 2003. [Relatório para a UNESCO da Comissão Internacional sobre Educação para o Século XXI]. Dicionário eletrônico da língua portuguesa [CD ROM]: Objetiva; 2001. 
Domingues TAM, Chaves EC. Os valores das enfermeiras na intenção do agir ético. Rev Esc Enferm USP. 2005; 39 (n. esp): 580-8.

Domingues TAM. Os valores das enfermeiras na intenção do agir ético [tese]. São Paulo: Escola de Enfermagem, Universidade de São Paulo, 2004.

Egry EY. Saúde coletiva: construindo um novo método em enfermagem. São Paulo: Ícone; 1996.

Ermel RC, Fracolli, LA. O trabalho das enfermeiras no Programa de Saúde da Família em Marília/SP. Rev Esc Enferm USP. 2006; 40(4): 533-9.

Fonseca RMGS. Uma leitura generificada da (re)inauguração de um fazer para mulheres: da Inglaterra ao Brasil. Rer. Bras. Enferm. 2002; 55 (1): p. 75-84.

Fonseca RMGS; Egry EY ; Marques CMS. O saber-ser éticoprofissional de trabalhadores da enfermagem: uma proposta desafiadora. In: Anais do $58^{\circ}$ Congresso Brasileiro de Enfermagem, 2006; Salvador BR. Salvador : Associação Brasileira de Enfermagem, 2006.

Fonseca RMGS, Egry EY, Bertolozzi MR. O materialismo histórico dialético como teoria da cognição e método para a compreensão do processo saúde-doença. In: Egry EY, Cubas MR, organizadora. O trabalho da enfermagem em saúde coletiva no cenário CIPESC. Curitiba: Mult-Grafic, 2006.p.19-61.

Fonseca RMGS. O saber ser e a prática profissional de enfermagem: um olhar de gênero. In: Anais do VI Forum Mineiro de Enfermagem; 2008; Uberlândia, BR. Uberaba: Universidade Federal de Uberlândia,; 2008. p. 53-69.

Forcella HT, Fonseca RMGS, Pimentel GMG. Vivendo valores no trabalho. Ed. para a Saúde. 2005; p.53-59

Fracolli LA, Bertolozzi MR. A Abordagem do Processo Saúde-Doença das Famílias e do Coletivo. In: Brasil. Ministério da Saúde. Universidade de São Paulo. Instituto para o Desenvolvimento da Saúde. Manual de Enfermagem. Brasília: Ministério da Saúde, 2001. p. 4-8.

Freitas GF. A responsabilidade ética-legal do enfermeiro. In: Oguisso T. organizadora. Trajetória histórica e legal de enfermagem. $2^{a}$ edição. São Paulo: Manoel; 2007. p. 209 - 236. 
Freitas GF. Conceituação sobre direito e normas éticas e legais. In: Oguisso T. organizadora. Trajetória histórica e legal de enfermagem. $2^{a}$ edição. São Paulo: Manoel; 2007. p. 195 - 208.

Heller A. O cotidiano e a História. $4^{a}$ edição. Rio de janeiro. Paz e Terra; 1992.

Higa EFR, Trevizan MA. Os Estilos de Liderança Idealizados pelos Enfermeiros. Rev Latino-am Enferm. 2005; 13(1): 59-64.

Leonello VM, Oliveira MAC. Construindo competências para ação educativa da enfermeira na atenção básica. Rev Esc Enferm USP. 2007; 41 (n. esp): 847-52. (b)

Leonello VM. Competências para ação da enfermeira: uma interface entre o ensino e assistência de enfermagem [dissertação]. São Paulo: Escola de Enfermagem, Universidade de São Paulo; 2007. (a)

Marques CMS. As competências crítico-emancipatórias e a formação dos trabalhadores de nivel médio em enfermagem: focalizando as politicas ministeriais [dissertação]. São Paulo: Escola de Enfermagem, Universidade de São Paulo, 2007.

Matumoto, S. et al. Supervisão de equipes no Programa de Saúde da Família: reflexões acerca do desafio da produção de cuidados.

Comunic., Saúde, Educ. 2005; 9 (16):9-24.

Merhy EE. A perda da dimensão cuidadora na produção da saúde uma discussão do modelo assistencial e da intervenção no seu modo de trabalhar a assistência. In: Campos CR, Malta DC, Reis AT, Santos AF, Merhy EE, organizadores. Sistema Único de Saúde em Belo Horizonte: reescrevendo o público. São Paulo: Xamã; 1998. p. 103-20.

Minayo MCS. O desafio do conhecimento. Pesquisa qualitativa em saúde. 9a ed. São Paulo: Hucitec; 2006.

Moreira TA. Compreendendo a vivência do paciente cuidado por aluno de enfermagem [dissertação]. São Paulo: Escola de Enfermagem, Universidade de São Paulo, 1998.

Morvant C, Lazimi G, Piet E. Les profissionnels de santé ont um role à jouer dans la lutte contre lês violences faites aux femmes: une urgence de santé publique. Disponivel em:http:/ / www.violences.fr/Actualités /Manifestedu8mars/tabid/94/ Default.aspx. Acessado em março de 2009.

Nakamura E. et al. Cenário Capão Redondo. In: Egry EY. Guia para pesquisadores: As necessidades em saúde na perspectiva da Atenção Básica. São Paulo: Dedone. No prelo. 
Oliveira CC, Fonseca RMGS. Práticas dos profissionais das equipes de saúde da família mulheres em situação de violência sexual. Rev Esc Enferm USP. 2007; 41(4):605-12.

Oliveira ML, Guilhem D. O agir ético na prática profissional cotidiana das enfermeiras. Rev. Bras. Enferm. 2001; 54(1): 63-73.

Padilha MICS, Mancia JR. Florence Nightingale e as irmãs de caridade: revisitando a história. Rev Bras Enferm USP. 2005; 58(6): 723-6.

Pires MRGM. Politicidade do cuidado e processo de trabalho em saúde: conhecer para cuidar melhor, cuidar para confrontar, cuidar para emancipar. Ciên e Saúde Colet. 2005; 10(4): 1025-35.

PMSP, Prefeitura do Município de São Paulo. Sumário de dados do municipio de São Paulo 2004. Disponível em: $<$ http://portal.prefeitura.sp.gov.br/secretarias/governo/sumario_dad os/0002 >. Acesso em: 31 de out. 2008.

Rodrigues, TMCM. O cuidar de enfermagem como ação terapêutica na atenção à saúde coletiva. In: Anais do $50^{\circ}$ Congresso Brasileiro de Enfermagem; 1998 set. 20-25; Salvador, BR. Salvador: Associação Brasileira de Enfermagem - Seção Bahia; 1998. p. 147-50.

Rosa MTL. Reflexão acerca da assistência de enfermagem ao indivíduo como ser social [dissertação]. São Paulo: Escola de Enfermagem, Universidade de São Paulo, 1985.

São Paulo (Município). Decreto n. 45.037, de 20 de julho de 2004. Dispõe sobre a organização do Sistema Único de Saúde no Município de São Paulo. Diário Oficial do Município de São Paulo, São Paulo, 21 jul. 2004; 49(136): 1-2.

São Paulo (Município). Lei n. 13.399, de $1^{\circ}$ de agosto de 2002. Dispõe sobre a criação, estrutura e atribuições das Subprefeituras no Município de São Paulo, estabelece procedimentos para sua implantação e prevê a transferência gradual de órgãos e funções da Administração Direta Municipal. Diário Oficial do Município, São Paulo, 2 ago. 2002;47.

SINASC . [base de dados na internet]. São Paulo: Secretaria Municipal de Saúde; 2008. Disponível http://www.nossasaopaulo.org. $\mathrm{br} /$ observatorio/regioes.php?tema $=10$ \&indicador $=134 \&$ regiao. . Acessado março de 2009

Sistema Estadual de Análise de Dados (SEADE). Índice de Vulnerabilidade Juvenil. SEADE; 2007 [texto na Internet]. Disponível em: http://www.seade.gov.br/produtos/ivj/. Acessado em março de 2009 
Silva LT, Zoboli ELCP, Borges ALV. Bioética e Atenção Básica: um estudo exploratório dos problemas éticos vividos por enfermeiros e médicos no PSF. Cogitare Enferm. 2006; 11(2):133-42.

Steinberg, L. Mattos, ILB. Cidadania, ética e moral: para viver melhor com nossos semelhantes. Ed. para a Saúde. 2005; p.47-52.

Taffer VBM. Dilemas éticos: a percepção de enfermeiros de instituições de medicina diagnostica [dissertação]. São Paulo: Escola de Enfermagem da Universidade de São Paulo, 2005.

Trevizan MA.; Mendes IAC, Fávero N, Melo MRA. Liderança e comunicação no cenário da gestão em enfermagem. Rev. latino-am. Enfermagem. 1998; 6 (5): 77-82.

Vázquez, AS. Ética. 29 ed. Rio de Janeiro: Civilização Brasileira; 2007.

Waldow VR. O cuidado na Saúde-As relações entre o eu, o outro e o cosmos. Petrópolis: Vozes; 2004.

Waldow, VR. Atualização do cuidar. AQUICHAN. 2008; 8 (1): 85-96. (b)

Waldow, VR. Bases e princípios do conhecimento e da arte da enfermagem. Rio de Janeiro: Vozes; 2008. (c)

Zoboli ELCP. Bioética e Atenção Básica: Um estudo de Ética descritiva com enfermeiros e médicos do Programa Saúde da Família [tese]. São Paulo: Faculdade de Saúde Pública, da Universidade de São Paulo, 2003. 


\section{APÊNDICE 1 - Caracterização sócio-econômica dos participantes}

\section{Caracterização das participantes}

Idade:

Estado civil: casada ( ) solteira( ) viúva( ) divorciada( ) desquitada( )

Condição marital: convive com algum parceiro sim ( ) não( )

Tem filhos vivos? Sim ( ) Não( ) Quantos?

Escola em que concluiu a graduação de Enfermagem:

Tempo de formada:

Outra formação:

Escola e ano da outra formação:

Local de Trabalho como enfermeira:

1 - Instituição

Seção, serviço, clínica ou departamento.

Tempo de trabalho neste local (último)

2. Outro local de trabalho como Enfermeira:

Instituição:

Seção, serviço, clínica ou departamento

Tempo de trabalho nesta instituição

Tempo total de trabalho como enfermeira:

Função / funções que exerce atualmente (listar as principais):

Local da Entrevista:

Data da entrevista: 


\section{APÊNDICE 2 - Roteiro de entrevista individual com a Equipe de Saúde da Família}

\section{Roteiro de coleta das situações}

Iniciais da entrevistada:

- Conte para mim, em detalhes, um fato vivenciado ou conhecido por você (que ocorreu realmente) de prestação de assistência e do qual tenham participado, além de você, enfermeira ou outros profissionais de saúde. Deverá ter tido também pelo menos uma pessoa atendida por você ou por algum outro membro da equipe de saúde. Pode ser um fato que aconteceu em hospital, ambulatório, centro de saúde ou em outro local de trabalho relacionado à saúde. Procure lembrar-se de um fato que tenha chamado sua atenção por algum motivo.

- O que você pensou e sentiu, naquele momento, a respeito do que aconteceu?

- O que você pensa e sente hoje a respeito daquele fato?

- Como sua formação profissional influenciou no seu modo de pensar e agir diante da situação apresentada?

Nome da entrevistadora:

Data de realização da entrevista: 


\section{APÊNDICE 3 - Termo de Consentimento Livre e Esclarecido}

Termo de Consentimento Livre e Esclarecido

Você está sendo convidada para participar voluntariamente da pesquisa intitulada "Competência Profissional: a dimensão do saber-ser ético profissional nas práticas de saúde das enfermeiras em unidade básica de saúde" desenvolvida pela mestranda Maria Cecília Ribeiro pelo Programa de PósGraduação em Enfermagem da Escola de Enfermagem da USP, área de concentração Saúde Coletiva. O estudo tem os seguintes objetivos:

- Conhecer situações do cotidiano da prática profissional das enfermeiras em unidade básica de saúde onde possam ser identificados elementos relacionados à dimensão do saber-ser da competência profissional.

- Verificar a aplicabilidade dos marcadores do saber-ser éticoprofissional desenvolvido para o auxiliar de enfermagem para as enfermeiras da UBS

Sua participação é voluntária e consiste em responder a algumas perguntas e relatar uma situação vivenciada por você na prática profissional de enfermagem. Serão garantidos o seu anonimato e o sigilo das informações. Os resultados serão utilizados exclusivamente para fins científicos. Durante a pesquisa você poderá fazer todas as perguntas que julgar necessárias para o esclarecimento de dúvidas, podendo deixar de participar do estudo a qualquer momento, se assim o desejar. Para aceitar participar da pesquisa nas condições descritas acima, você deve ler e depois assinar a declaração a seguir:

Como participante da pesquisa afirmo que fui devidamente orientada sobre a finalidade e objetivos da pesquisa, bem como sobre a utilização das informações que forneci somente para fins científicos, sendo que meu nome será mantido em sigilo. Minhas dúvidas foram esclarecidas suficientemente e autorizo a realização da entrevista, da gravação de minha fala do relato que fiz de uma situação vivenciada. Declaro que concordo com a utilização de todos estes dados nesta pesquisa.

Pesquisadora: (nome e assinatura)

São Paulo, / 2008

Pesquisadora: Maria Cecília Ribeiro. Mestranda da Escola de Enfermagem da Universidade de São Paulo. SCHES quadra 305 bloco A apto 402. Cruzeiro Novo DF. Fones: (0XX61) 8125-5012.

Telefone do Comitê de Ética em Pesquisa da EEUSP - (OXX11) 3066-7503. 


\section{ANEXO 1 - Marcadores do saber-ser ético-profissional do Auxiliar de Enfermagem}

\begin{tabular}{|c|c|}
\hline Marcadores & Significado \\
\hline $\begin{array}{l}\text { 1- Compreender o âmbito } \\
\text { das ações da enfermagem } \\
\text { na produção de serviço de } \\
\text { saúde. }\end{array}$ & $\begin{array}{l}\text { Compreender as finalidades e os objetivos das ações que } \\
\text { realiza; compreender o seu trabalho como totalidade parte } \\
\text { do trabalho de enfermagem e de saúde; reconhecer o âmbito } \\
\text { e os limites da sua atuação profissional e agir de acordo com } \\
\text { a legislação vigente. }\end{array}$ \\
\hline $\begin{array}{l}\text { 2- Mobilizar saberes para } \\
\text { avaliar contextos e tomar } \\
\text { decisões. }\end{array}$ & $\begin{array}{l}\text { Relacionar o condicionamento e a experiência profissional } \\
\text { com o contexto para enfrentar as situações, avaliando e } \\
\text { propondo ao adotando soluções. }\end{array}$ \\
\hline $\begin{array}{l}\text { 3- Interagir com o usuário e } \\
\text { seus familiares, } \\
\text { demonstrando atenção às } \\
\text { várias formas de } \\
\text { manifestação de suas } \\
\text { necessidades e demandas. }\end{array}$ & $\begin{array}{l}\text { Compreender a linguagem verbal do usuário, percebendo, } \\
\text { ouvindo e compreendendo as razões que motivam suas } \\
\text { atitudes e comportamentos. Esta interação se expressa na } \\
\text { adoção de principios e valores como: bondade, compaixão, } \\
\text { cooperação, empatia, generosidade, honestidade, } \\
\text { humanidade, iniciativa, justiça, lealdade, respeito, } \\
\text { solidariedade e tolerância. }\end{array}$ \\
\hline $\begin{array}{l}\text { 4- Perceber, compreender e } \\
\text { respeitar-se como cidadão e } \\
\text { como trabalhador de saúde. }\end{array}$ & $\begin{array}{l}\text { Ter apreço para consigo mesmo e para com o próprio } \\
\text { trabalho, reconhecer e exercitar seus direitos, sua } \\
\text { autonomia e auto-desenvolvimento; respeitar os seus } \\
\text { próprios sentimentos, atitudes e valores éticos-morais } \\
\text { considerando o bem-estar e os direitos dos usuários. }\end{array}$ \\
\hline $\begin{array}{l}\text { 5-Demonstrar } \\
\text { responsabilidade para com } \\
\text { usuários e equipe nas } \\
\text { situações de trabalho. }\end{array}$ & $\begin{array}{l}\text { Corresponde à maneira subjetiva que cada trabalhador } \\
\text { apreende as situações de trabalho e se situa em relações a } \\
\text { elas, dimensionando as ações que são necessárias para } \\
\text { enfrentá-la. A responsabilidade se expressa pelo } \\
\text { compromisso e reciprocidade (interação) entre as pessoas } \\
\text { envolvidas com um conjunto de ações, em prol da qualidade } \\
\text { da assistência. }\end{array}$ \\
\hline $\begin{array}{l}\text { 6- Interagir com equipe de } \\
\text { trabalho de acordo com os } \\
\text { valores que regem o } \\
\text { trabalho da enfermagem. }\end{array}$ & $\begin{array}{l}\text { Pressupõe articular-se com a equipe de trabalho, num } \\
\text { movimento de solidariedade e de compartilhamento, } \\
\text { assumindo co-responsabilidade e reconhecimento das } \\
\text { competências dos outros. Visa ao eficaz resultado das ações } \\
\text { e procedimentos que realiza. }\end{array}$ \\
\hline $\begin{array}{l}\text { 7- Respeitar os direitos dos } \\
\text { usuários como cidadãos. }\end{array}$ & $\begin{array}{l}\text { Compreender que os usuários têm direito à assistência de } \\
\text { qualidade. Compreender que a saúde é um direito do } \\
\text { usuário como cidadão brasileiro e um dever do estado. } \\
\text { Reconhece a autonomia do usuário em relação à sua própria } \\
\text { saúde }\end{array}$ \\
\hline $\begin{array}{l}\text { 8- Compreender } \mathrm{e} \\
\text { posicionar-se frente às } \\
\text { condições de trabalho } \\
\text { existentes nas instituições. }\end{array}$ & $\begin{array}{l}\text { Compreender e posicionar-se em relação aos efeitos da } \\
\text { organização e das condições de trabalho sobre os } \\
\text { trabalhadores, usuários e sobre o próprio processo de } \\
\text { trabalho em saúde. }\end{array}$ \\
\hline
\end{tabular}

Fonte: Marques, 2007. 


\title{
ANEXO 2 - Parecer do Comitê de Ética da Escola de Enfermagem da USP
}

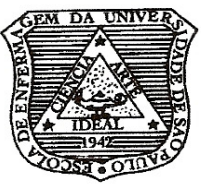

\author{
UNIVERSIDADE DE SÃO PAULO \\ ESCOLA DE ENFERMAGEM \\ Av. Dr. Enéas de Carvalho Aguiar, 419 - CEP 05403-000 \\ 2: Fone: $3061-7548$ - Fax.: 3061-7548 \\ C.P. 41633 - CEP 05422-970 - e-mail.: edipesq@usp.br
}

São Paulo, 13 de junho de 2008.

Ilm. ${ }^{\text {a }} \mathrm{Sr}^{\text {a }}$

Maria Cecília Ribeiro

Ref.: Processo $\mathrm{n}^{\circ}$ 730/2008/CEP-EEUSP

Prezada Senhora,

Em atenção à solicitação referente à análise do projeto "Competência Profissional: a dimensão do saber-ser ético profissional nas práticas de saúde das enfermeiras em unidade básica de saúde", informamos que o mesmo foi considerado aprovado pelo Comitê de Ética em Pesquisa da Escola de Enfermagem da Universidade de São Paulo (CEP/EEUSP).

Analisado sob o aspecto ético-legal, atende às exigências da Resolução no 196/96 do Conselho Nacional de Saúde.

Esclarecemos que após o término da pesquisa, os resultados obtidos deverão ser encaminhados ao CEP/EEUSP, para serem anexados ao processo.

Atenciosamente,

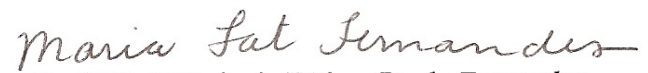

Prof. ${ }^{a}$ Dr. ${ }^{a}$ Maria de Fátima Prado Fernandes

Coordenadora do Comitê de Ética em Pesquisa da

Escola de Enfermagem da Universidade de São Paulo 